\title{
Promoting Rule Compliance in Daily-Life: Evidence from a Randomized Field Experiment in the Public Libraries of Barcelona*
}

\author{
Jose Apesteguia Patricia Funk Nagore Iriberri ${ }^{\dagger}$
}

August 2010

\begin{abstract}
We study how to promote compliance with rules in everyday situations. Having access to unique data on the universe of users of all public libraries in Barcelona, we test the effect of sending email messages with different contents. We find that users return their items earlier if asked to do so in a simple email. Emails reminding users of the penalties associated with late returns are more effective than emails with just a generic reminder. We find differential treatment effects by user types. The characteristics we analyze are previous compliance, gender, age, and nationality.
\end{abstract}

Keywords: Rule Compliance, Pro-Social Behavior, Field Experiment, Public Libraries.

JEL classification numbers: C93, D01, D03, D63, K42.

*We are grateful to Anna Surroca (Serveis de Biblioteques of the Diputacio de Barcelona), Judit Terma (Consorci de Biblioteques de Barcelona), and their respective teams, for their collaboration and assistance in conducting this study. We thank Antonio Cabrales, Pablo Casas, Vincent P. Crawford, Uri Gneezy, Rosemarie Nagel, Imran Rasul, Pedro Rey-Biel and Carmit Segal for helpful comments. Special thanks go to Stephan Litschig for constant feedback and discussions. Sergio Correia provided excellent research assistance. Financial support from the Spanish Commission of Science and Technology (ECO2008-01768, ECO2009-12836, ECO2009-11213 and SEJ2007-64340), Fundación Rafael el Pino, the Barcelona GSE research network, and the Government of Catalonia is gratefully acknowledged.

${ }^{\dagger}$ Universitat Pompeu Fabra and Barcelona GSE. E-mails: jose.apesteguia@upf.edu, patricia.funk@upf.edu, and nagore.iriberri@upf.edu. 


\section{Introduction}

Understanding compliance with rules and social norms is crucial for modern societies. No matter whether we talk about littering on the streets, picking up children from the kindergarten on time, or appropriate behavior in public places like metros or libraries, learning about effective tools for promoting compliance with norms is of obvious importance. While economists would naturally think about monetary incentives, it has been found that they may backfire (see Benabou and Tirole, 2003 and 2006, for theoretical arguments; Gneezy and Rustichini, 2000, and Mellstroem and Johannesson, 2008, for empirical studies), or that they are not feasible due to political and institutional restrictions. Therefore, it is crucial to understand whether there are other possible ways to promote compliance with norms. The goal of this paper is to analyze the effect of conveying various types of messages, in our case by email.

A setting that allows us to study compliance with rules on a large scale is the Network of Public Libraries in the city of Barcelona. The type of compliant behavior we analyze is whether users of the libraries return the items they borrowed on time. A user not returning an item by the due date is violating the norm, and potentially generating a negative externality on the population of users. We evaluate whether we can get users to return the items they borrow earlier; by means of different email contents that are randomly allocated. Our interest in the potential effects of sending emails is that it offers a virtually costless and non-invasive intervention mechanism that is simple to implement and very flexible for our, as well as for other applications. Despite the advantages of this message intervention, little is known about its effectiveness. ${ }^{1}$

There are important characteristics that make our study unique. First, we observe the behavior of all users of all public libraries in Barcelona over eleven months. During this time span, there were about 50,000 different users, who borrowed over a million items in the 32 different libraries spread throughout the city of Barcelona. Therefore, we have data on a large number of individuals, in a daily-life situation, taking part in their natural environment, and over an extended period of time. Second, we observe every

\footnotetext{
${ }^{1}$ The provision of messages as a mechanism for promoting certain types of behavior is, of course, used in practice. As an illustration, in many countries the driving authorities convey messages to drivers by way of electronic panels in the roads, with the aim of promoting careful driving. Such messages, for example, include reminders of the penalties associated with breaking driving norms. However, the effect of these messages are, to the best of our knowledge, unknown.
} 
borrowing-returning transaction of items made by users. This allows us to measure compliant behavior with great precision. In other words, we are able to determine exactly when individuals conform with the norm and when they violate it, and if so, how severe these violations are. Third, the rules that govern the interaction between the users and the libraries are simple and well-defined. In particular, the penalty associated with returning an item late does not involve any monetary fines, but only the exclusion from the possibility of borrowing more items for a time period equal to the number of days the item is overdue. Finally, the rich data on users offers a unique opportunity to test for differential treatment effects depending on important demographic variables, such as gender, age and nationality.

We randomize all users into groups receiving one of five different email messages, and study their behavior after receiving the email. One of the five email messages is a Control message that simply points to a link to the webpage of the Network of Libraries. $^{2}$ All the remaining messages add content to the text in ConTrol. The first treatment message, called REMINDER, represents a general reminder of the users' duty to return the borrowed items on time. The second message, Social, adds to REMINDER an appeal to the effect individual behavior can have on the overall functioning of the public library services, besides pointing out its importance. The last two email treatments, LATE and PENALTY, are targeted only at those users who have recently returned at least one item late. Both LATE and PENALTY add to Reminder the identification of the user as having recently returned items late. Finally, PENALTY builds on LATE and adds a reminder of the penalties associated with non-compliant behavior.

These email treatments allow us to evaluate the power of different message contents to affect users' behavior. For example, we can test whether contents appealing to the social problem of returning an item late are more effective than a generic reminder to return the borrowed items on time, or, similarly, we can test whether being identified in an email as a recent non-complier is more effective than a generic reminder. Given our design, we study the effect of email treatments on all users, independent of whether they were initially complying with the rule or not, by comparing CONTROL, REMINDER and

\footnotetext{
${ }^{2}$ The idea is that by comparing the effect of the treatment messages relative to the control, we are able to differentiate between the effect of the content of a treatment message and that of just getting an email from the Network of Libraries.
} 
SOCIAL; and the effect on previous non-compliers by comparing CONTROL, REMINDER, Social, Late and Penalty.

In our analysis we evaluate the effect of emails on the proportion of late returned items by user, and on the number of days that elapse between the return date and the due date. The first variable measures the propensity to comply with the norm, while the second variable measures the positive/negative externality that is imposed on other users when a user returns the item earlier/later than the due date.

Our main result is that compliant behavior can be promoted by sending a simple email. All emails significantly reduce both, the proportion of late returned items, and the number of days between the return date and the due date. The greatest effect comes from the PENALTY treatment, reducing the proportion of late returned items by 4.3 percentage points, which has a significantly greater effect than the general REMINDER (2.3 percentage points). The effects are not only statistically significant but also economically relevant, especially in light of the negligible costs associated with the intervention.

As for the effectiveness over time, we show that the effect of getting one of these emails is short-term; the effect is significant during the first month after the email intervention, but not afterwards. However, the effect is reproduced when the same email is received for a second time, in our case two and a half months later. As such, our results suggest that sending multiple emails helps to keep compliance high.

Our data also allow us to study the effects on behavior by user-type. Regarding previous compliance, we find that users with a higher proportion of late returns in the pre-treatment period react more strongly than users with a lower proportion of late returns. Interestingly, even the "good citizens" react positively to receiving an email. Hence, the email treatment is more effective precisely with those users whose compliance prior to the treatment was lower, and, importantly, does not generate crowdingout effects in those users that were complying with the rule before the intervention. We also find different effects by age groups. For example, we show that users under the age of 20 do not react to any email content in terms of the proportion of late items per user, while users in the age classes 20 to 40 and 40 to 60 are generally responsive to receiving the emails. Users between 40 and 60, and over 60 seem to react mainly with regard to the PENALTY treatment. With respect to gender, our results show that there are no significant differences in reactions to the treatments between women 
and men. Finally, there are wide variations that depend on the users' nationality. We study reactions of users from Spain, Northern-Central Europe, Western and Southern Europe, English speaking countries (UK, USA, CA), East Europe and Russia, Latin America, Asia and Africa. Interestingly, only Spaniards, people from English speaking countries and Asians react to the emails. We then evaluate whether Asians or citizens of English speaking countries react differently to the treatments than Spaniards do. Here, we see that users from English speaking or Asian countries react much more strongly than Spaniards. For example, compared to Spaniards, their propensity to be late after treatment is lower by up to 26 percentage points.

Our results relate to different strands of literature. Most directly, our study fits into the growing literature on how to promote pro-social behavior and compliance with rules. ${ }^{3}$ There is evidence that visibility of good/bad behavior may induce compliant/prosocial behavior due to social sanctions and social rewards (Gerber, Green, and Larimer, 2008; Funk, 2010). Also, allowing for free communication between interacting agents before they take actions has proven to change outcomes in specific experimental settings that broadly relate to pro-social behavior, such as hold-up problem games (Ellingsen and Johannesson, 2004), trust games and hidden-information games (Charness and Dufwenberg, 2006; 2010) and dictator games (Ellingsen and Johannesson, 2008; Andreoni and Rao, 2010). However, relatively little is known about the effect of specific message contents on promoting pro-social behavior and compliance with rules. Relevant exceptions to the latter are Dal Bó and Dal Bó (2009) and Fellner, Sausgruber, and Traxler (2009).

Dal Bó and Dal Bó (2009) conducted a series of laboratory two-player public good experiments to study the influence on individual contribution levels when players receive a message appealing to moral rules. They showed that receiving a message with a moral standard increases contribution levels, although the effect is transitory. Furthermore, if the moral message comes in a setting where individuals can punish the opponent in the public good game, the increase in the contribution levels is more stable. Fellner, Sausgruber, and Traxler (2009) studied the effect of different mailings to potential evaders of TV license fees. Their mailings included a legal threat, a moral

\footnotetext{
${ }^{3}$ While pro-social behavior usually refers to actions that mainly benefit others, compliance with rules involves elements of pro-social behavior if the penalty is small. In our case, returning items on time most likely involves both, compliance with rules and pro-social behavior.
} 
appeal, and information on average compliance rates. They found that the legal threat mailing significantly increases compliance rates, while neither the moral appeal nor the social information mailings have any effect.

Our study complements these papers. We complement Dal Bó and Dal Bó (2009) by providing evidence from a field experiment that studies the effect of sending messages in a natural environment. The main difference to Fellner, Sausgruber, and Traxler (2009) is that we can measure compliance and non-compliance with great precision and study the effect of messages on these different types of behavior. Furthermore, our data on user characteristics allow us to study differential effects with regard to gender, age and nationality. Finally, their setting and ours also differ in terms of the associated penalties for non-compliance. While in their case these are very high, in ours they are relatively minor.

Our findings are also relevant for a growing literature that investigates gender differences in preferences and behavior (e.g. Andreoni and Vesterlund, 2001; Charness and Gneezy, 2007; Charness and Rustichini, 2009; Croson and Buchan, 1999; and Niederle and Vesterlund, 2007; see Croson and Gneezy, 2009, for a comprehensive and exhaustive survey). Evidence on gender differences in social preferences, altruistic behavior and cooperation seems to be mixed. Croson and Gneezy (2009) suggest that this is likely to be due to women being more sensitive to the experimental context than men. Our study complements this literature by studying gender differences on norm compliance in an everyday and natural situation (see Levitt and List, 2007). We find that there are no significant differences by sex in reactions to the email intervention.

Finally, our paper is also relevant for a strand of literature that investigates the effects of culture on behavior. There is evidence that culture matters in a variety of outcomes, such as labor force participation and fertility (Fernandez, 2007a; Fernandez, 2007b), economic exchange (Guiso, Sapienza and Zingales, 2009), redistribution (Luttmer and Singhal, 2010; Fong and Luttmer, 2009), cooperation (Herrmann, Thöni and Gächter, 2008; Gächter, Herrmann and Thöni, 2010), and, most related to our study, violations of rules and norms (Fisman and Miguel, 2007). ${ }^{4}$ Our study is consistent with Fisman and Miguel (2007) in that there are major differences in compliant

\footnotetext{
${ }^{4}$ Fisman and Miguel (2007) study parking violations by diplomats in New York City. Since diplomats could not be fined due to diplomatic immunity, the setting allowed the analysis of which nationalities were more likely to break rules in an environment of zero punishment.
} 
behavior by individuals with different countries of origin. To start with, we find that Asian people comply with rules more than other nationalities. Also, they react quite strongly to receiving emails, together with people from English speaking countries. Finally there are groups of countries (Western-Southern Europe, Russia, Latin America), where compliance is poor to begin with, and there is little reaction to receiving emails from libraries.

The remainder of this paper is organized as follows. Section 2 describes the setting, namely the Network of Public Libraries in the city of Barcelona, and explains in detail the design of the field experiment, as well as the identification strategy. Section 3 is devoted to the presentation and discussion of the results. Finally, Section 4 presents conclusions.

\section{The Field Experiment}

\subsection{The Setting: Network of Public Libraries of Barcelona}

The Network of Public Libraries in the city of Barcelona is managed by a central body dependent on the City Hall of Barcelona and the Government of the Province of Barcelona. It encompasses 32 libraries spread throughout the city of Barcelona. Each library offers the possibility of borrowing items such as books, DVDs, CDs and magazines; other services such as internet access, exhibitions and workshops are also provided.

The rules governing the borrowing of different item types are clearly defined and are the same for all the 32 libraries. At the time of our study, a book could be borrowed for 21 days, while all other item types (DVDs, CDs and magazines) could be borrowed for 7 days. Users could also explicitly ask to extend the due date if no other user required that item. As for the maximum number of items to be taken, each user could simultaneously take a total of 30 items, 15 books and magazines, and $15 \mathrm{CDs}$ and DVDs. The penalty associated with returning an item late involved being barred from borrowing new items for a time period equivalent to the number of days elapsed between the due date and the actual return day. In particular, there was no monetary fine associated with not complying with the return policy. 


\subsection{Data}

We observed the complete borrowing/returning behavior for every single user at the Network of Public Libraries of Barcelona from January 2009 until the beginning of November 2009. This included any user at any of the 32 public libraries in Barcelona. For every transaction we observed (i) the user code, gender, age, and nationality, (ii) the item code and its characteristics, that is, whether it was a book, DVD, CD, or magazine, (iii) the dates of the transaction, that is, the date when the item was borrowed and returned, and (iv) the library where the transaction took place. With this information we were able to follow the exact borrowing behavior of every single user of the Network of Public Libraries in Barcelona. Given that our design is based on emails, we concentrate on the sample of those users with a known email. ${ }^{5}$ This gives us about 50,000 different users, who borrowed over a million items.

The data set encompasses a diverse set of users in terms of individual characteristics (age, gender and nationality), but also in terms of their borrowing behavior. In particular, we observe the type of items they borrow (books, or other item types), whether they are compliant or not, as well as whether they are persistent late returners. Furthermore, libraries also present significant differences in terms of their size, both in terms of number of users and number of transactions, location and proportion of late returners.

\subsection{Email Contents}

The Network of Public Libraries in the city of Barcelona maintains constant communication with its users via email. Most emails include information on the activities organized in the different libraries of the city, such as exhibitions or workshops, and on opening hours. In collaboration with the Network, we designed five different email messages (see Table 1) that were randomly assigned to the users. The objective of the study is to evaluate the impact of these messages on users' behavior.

[Table 1 here]

As can be seen from Table 1, ConTrol refers to the control treatment. It simply shows a link to the webpage of the Network of Public Libraries in Barcelona. The rest

\footnotetext{
${ }^{5}$ The Network of Public Libraries knows the email addresses of about $40 \%$ of the registered users.
} 
of the treatment messages build on CONTROL, adding different pieces of information. REMINDER represents a general reminder to return items on time. Note that this general reminder (and the other treatments as well) do not include any reference to particular items that were borrowed at the time of receiving the email. Therefore, it can be directed to all users, regardless of whether they had borrowed any item at the time of receiving the message. SocIAL builds on REMINDER, incorporating a moral and social dimension. It adds an appeal to the influence of individual behavior on the proper overall functioning of the public system of libraries. These two emails, REMINDER and SociAL, together with CONTROL, were designed to target any possible user, regardless of whether the user had returned some items later than the due date in the recent past. The final two emails were specifically designed to target users with late returns in the recent past. Email LATE adds to the content of REMINDER a statement that identifies the user as having recently returned an item late. Finally, Penalty builds on Late adding a reminder of the actual penalty associated with returning an item late.

In our analysis, we will compare the effect of receiving a REMINDER, SocIAL, LATE or Penalty email, with that of receiving Control. That is, we will study whether any of the four treatments improves with respect to a CONTROL message. Furthermore, the contents of the emails potentially allow us to distinguish between different motives for behavioral changes. For example, the difference in the texts between REMINDER and SociAL allows us to evaluate whether appealing to the importance of one's contribution to the good functioning of a public service is more effective than a generic reminder. Comparing LATE with REMINDER is useful to test whether being identified as noncompliant with the norm has a different effect than the generic reminder. Finally, PENALTY allows us to test for any differential effect of recalling the penalties associated with violation of the norm.

It was our aim to design emails with general contents that could be applied to many settings of interest beside libraries. For this reason, no email makes any reference to particular items that may have been borrowed at the time of receiving the email. Also, we kept in mind that not all settings permit the type of precise data on individual behavior that we had at the moment of treatment (e.g., identifying users as late and non-late). In this vein, three of our emails, Control, REMinder and Social, are general in the sense of not using any information on the behavior of users prior to the treatment, and can therefore easily be adapted to other settings (e.g. driving alerts, 
voting, donating blood, or referee reports). On top of that, for cases where information on individual behavior is available to the policy maker, it is important to analyze the potential effects on behavior of using such specific information. In our case, LATE and PENALTY use information on user history in order to directly target non-compliant individuals.

\subsection{Randomization}

In this section we describe the design and procedures of the field experiment. We start by presenting the timing of the email intervention, as well as the randomization of users into the control and different treatments. Then, we evaluate whether the random assignment of users to the control and different treatments was successfully accomplished. Finally, we comment on attrition rates.

As for the setup of the experiment, we sent emails in two different waves. Wave 1 was sent on July 1st, 2009, when we reached about 36,700 users. Wave 2 was sent on September 15th, 2009, when we reached about 38,300 users. Overall, we reached about 50,000 different users. ${ }^{6}$

In Wave 1 we considered all the active users between January 1st and May 5th, 2009 and classified them into two categories: late users and non-late users. An active user is a user who borrowed at least one item during the time interval mentioned. A late user is a user who returned an item after the due date at least once during the time interval mentioned. A non-late user is a user who did not return any item late during the time interval. There were a total of 21,571 late users and 15,106 non-late users in Wave 1. Late users were randomly assigned to the five different treatments Control, Reminder, Social, Late and Penalty, while non-late users were randomly assigned to CONTROL, REMinder and Social only. Randomization was carried out at the library level.

In Wave 2 we considered all the active users between March 1st and July 31st, 2009. Note that in this case we have users who were already active in Wave 1 and new active users, namely those users who were active only between May and July. With

\footnotetext{
${ }^{6}$ In each wave we sent about 50,000 emails but not all emails were actually delivered. About 30\% of email addresses turned out to be invalid and the email messages were returned to the server as messages that were never delivered. We therefore restrict our analysis to those users, to whom the message was delivered.
} 
regard to the new active users, about 10,500 individuals, we repeated the randomization procedure as in Wave 1. We first classified the new active users into late and non-late users, 5,191 and 5,301 users, respectively. Second, late users were randomly assigned to the five treatments, while the non-late users were randomly assigned to the CONTROL, REMinder and Social treatments only. Also, as in Wave 1, randomization was done at the library level. The active users in Wave 2 who were also active in Wave 1 , about 28,500 individuals, received exactly the same email as in Wave 1. Exceptions were those users who were allocated to LATE or PenAlty in Wave 1 but who, during the interval between March 1st 2009 and July 31st 2009, were never late again. There were about 700 of such users, who were excluded from the randomization, and hence received no email in Wave 2. Therefore, there was a total of 20,556 late users and 17,725 non-late users in Wave 2.

Table 2 reports the descriptive statistics of all users, both non-late and late, who were randomly assigned to treatments Control, Reminder and Social in Waves 1 (top) and 2 (bottom). Table 3 reports the descriptive statistics of late users only, randomly assigned to the five treatments in Waves 1 (top) and 2 (bottom). Note that late users in Control, Reminder and Social appear in both Tables 2 and 3. The last column in Tables 2 and 3 report the $p$-values for the F-Test of equality of variable means across all groups.

[Tables 2 and 3 here]

Consistently with the random assignment of users to treatments, the average user has similar values in the observable characteristics across the different treatments. In fact, as shown by the $p$-values in the last column in both Tables 2 and 3 , the null hypothesis of equality in the means can rarely be rejected. An exception is the proportion of foreigners, possibly due to the valid email address correction (see footnote 6). However, the mean values do not show sizeable differences.

As for the characteristics of the average user in the Network of the Public Libraries in the city of Barcelona, $42 \%$ of users are male users and the proportion of foreigners is around $30 \%$. The average age is 33. The typical user also borrows quite frequently, with the average total number of loans between January and November exceeding 30. Finally, the majority of borrowed items are books (60\%), followed by DVDs (28\%) and CDs (9\%). Magazines comprise the least frequent type of loans. 
From Tables 2 and 3, we can also see the magnitude of the problem of late returns in the Network of Public Libraries in Barcelona. Overall, considering both late and non-late users, $30 \%$ of loans per user are returned later than the due date. Moreover, considering only those users who have been late at least once, around $60 \%$ of the loans per user are returned after the due date. Furthermore, the typical user returns the borrowed items on average more than a day and a half later than the due date when we consider all late and non-late users. When we only consider late users, the typical user returns the borrowed items on average 6.5 days later than the due date. This shows that returning items late is a common, extended and pervasive habit among the public library users in Barcelona.

In our analysis, as is standard practice in any randomized field experiment, we concentrate on the post-treatment period, that is, on the behavior of users after the email intervention. For those users who received the email message in Wave 1, the post-treatment starts on the 1st of July. For those users who got the email for the first time in Wave 2, the post-treatment starts on the 15th of September. However, not all users who received the email treatment appear in the post-treatment period, that is, some users do not borrow or return items at any time in the post-treatment period, so that we cannot observe compliant or non-compliant behavior. One important issue that needs to be addressed is whether the randomization is still valid when we look at those users whose behavior can actually be observed during the post-treatment period. In particular, we would like to know whether attrition rates between pre and posttreatment periods are significantly different across the control and treatment groups. To address this issue, we calculate the attrition rates, that is, the share of users who received the email treatment but who did not borrow or return any item in the posttreatment period. We do this separately for Waves 1 and 2, as shown in the last row of Tables 2 and 3. First, on average, between 54\% (Table 2) and 46\% (Table 3) of emailed users did not borrow or return any items in the post-treatment period. Second and most importantly, we can see from the F-Test of equality of means that there are no significant differences in attrition rates across the different control and treatment groups. $^{7}$ This rules out possible concerns about attrition being a handicap for the

\footnotetext{
${ }^{7}$ We also redid Tables 2 and 3 for those users who were treated and did borrow or return items in the post-treatment period. We obtained the same results, qualitatively speaking, showing that the control and treated groups are comparable in all the observable characteristics.
} 
interpretation of results.

\subsection{Identification Strategy}

We are interested in evaluating the effect of email messages on the behavior of users. We will focus on two different dependent variables. First, we look at the proportion of late returned items per user (Proportion Late). This is a direct measure of how users comply with the rule. Second, we use the average number of days between the return date and the due date per user ( Actual-Due" Date). When this difference is positive the item was returned late and when this difference is negative the item was returned early compared to the due date. In contrast to the first dependent variable, which measures late/non-late per item in a binary way, this second variable also takes into account the extent of late or early returns.

In a randomized experiment like ours, the causal effect of the treatments can be estimated as follows:

$$
Y_{i}=\alpha+\beta_{1} \text { Reminder }_{i}+\beta_{2} \text { Social }_{i}+\beta_{3} \text { Late }_{i}+\beta_{4} \text { Penalty }_{i}+\epsilon_{i}
$$

where the dependent variable $Y_{i}$ is either (i) the proportion of late returns per user, or (ii) the average number of days between the return date and the due date per user. ${ }^{8}$ Reminder, Social, Late, and Penalty are dummy variables taking a value of 1 when user $i$ was assigned to Reminder, or Social, or LATE, or Penalty, respectively. The omitted treatment to which these variables are compared is CONTROL.

Consistent with our design, we will estimate equation (1) in two different ways. First, we compare Reminder and Social to Control for all users, independent of whether they were late or not in the pre-treatment period. ${ }^{9}$ Second, we compare Reminder, Social, Late and Penalty to the Control restricted to all users who were late at least once in the pre-treatment period.

\footnotetext{
${ }^{8}$ Note that the dependent variables are obtained by collapsing all the transactions at the user level. For example, for a user with 5 transactions that was late with 4 of them has a proportion of late returns of $4 / 5$. In the subsequent analysis, when we add control variables, we also collapse them at the user level.

${ }^{9}$ Here, to be precise, we estimate $Y_{i}=\alpha+\beta_{1}$ Reminder $_{i}+\beta_{2}$ Social $_{i}+\epsilon_{i}$ for all users who received a Control, Reminder, or Social treatment.
} 


\section{Results}

\subsection{Average Treatment Effects}

We estimate equation (1) by OLS. Table 4 reports the results for Control, ReMINDER, and Social, covering all users, both late and non-late users, who got one of these emails in Waves 1 and 2. Table 5 reports the results for all five treatments restricted to the late users only.

[Tables 4 and 5 here]

The first three columns in both Tables 4 and 5 refer to the proportion of late returns per user, while the last three columns refer to the average number of days between the return date and due date per user. In both cases the first column reports the results of estimating equation (1) without any controls. The second column controls for users' demographics, such as gender, whether the user is foreign or not, and for different age intervals. It also includes controls for different months between July and November, as well as the number of borrowed items. Finally, in the second column we also add controls for users' behavior prior to the treatment, which measures their propensity for late returns and for the average number of days between the return date and the due date per user, prior to the treatment. The third column adds more controls in addition to all the previous variables, accounting for the item type (whether it refers to a book, DVD, CD or a magazine), as well as library fixed effects. ${ }^{10}$

We start by commenting on the results of Table 4. Both REMINDER and Social are significant and negative, showing that both email treatments significantly reduce the proportion of late returns and the number of days between the return date and the due date. Furthermore, the more controls we add, the smaller the standard errors become. Taking the estimates of the third column, receiving a REMINDER email decreases the proportion of late returns by 1.4 percentage points with respect to CONTROL, while in the case of SociaL, the reduction is 1.8 percentage points. Evaluated at the mean propensity for being late of approximately 33 percent (see Table 2), the reduction in late returns lies between 4.2 percent (REmindeR) and 5.5 percent (Social). Moreover, receiving a treatment email also significantly decreases the number of days between

\footnotetext{
${ }^{10}$ In all specifications, we discard transactions that were due on a holiday, when the library was closed.
} 
the return date and the due date: the REMINDER and Social emails decrease this difference on average by almost half a day with respect to ConTrol. Note also that the coefficients of the REMINDER and the SOCIAL emails are not statistically different, meaning that the moral suasion did not affect users' behavior differently from the general reminder.

From Table 5, when comparing all four treatments for users who were late at least once in the pre-treatment period, we see that all four of them are significant; both for the proportion of late returns per user and for the average number of days between the return date and the due date per user. For instance, from column (3) we see that the treatment effects (compared to the control) range from -2.4 percentage points for the Reminder to -4.3 percentage points for the Penalty. As for the number of days between the return date and the due date, the reduction lies between 0.54 and 0.87 days. Clearly, the most effective treatment seems to be the Penalty treatment, reducing the proportion of late returns per user by 4.3 percentage points and the average number of days between the return date and the due date per user by almost a day. Evaluated at the means (see Table 3), this corresponds to a reduction in 7 percent for the proportion of late returns, and a reduction of 13 percent for the number of days between the return and the due date. Moreover, for the proportion of late returns, the coefficient estimates of the REMINDER and PENALTy treatments are significantly different at the $5 \%$ level, showing that the late identification and the penalty reminder make a significant contribution on top of a general reminder.

One may wonder whether the effect mainly comes from the proportion of items that are pending at the time of receiving one of the email treatments or whether it is also the case that rule compliance improves more generally. This is important to understand when we think of the applicability to other settings. In order to address this question, we first create a variable, called Pending, which calculates the proportion of pending items per user at the time of receiving an email. Then, we interact the treatment dummies with the proportion of pending items at the user level. Table 6 reports the results.

[Table 6 here]

As can be seen, the interaction terms are insignificant for the proportion of late returns (columns (1) and (3)). Therefore, the effects found in Tables 4 and 5 came 
not only from the proportion of loans that were pending at the time of the email intervention; instead, the treatments affected all users' behavior, whether items were pending or not. On the other hand, for the average number of days between the return date and the due date (columns (2) and (4)), the interaction terms are negative and significant, implying that users with a larger proportion of pending items return their items earlier than users with a lower proportion of pending items.

To sum up, the results from this section show that a simple email is effective in promoting better compliance with rules. Furthermore, the results are highly robust with regard to other specifications. If instead of collapsing the data at the user level, we estimate random effects with transaction level data, the results we obtain are both qualitatively and quantitatively similar (available upon request). Finally, note again that the intervention mechanism is non-invasive, virtually costless and readily applicable to other settings. In this light, the capability to reduce the proportion of late returns by 7 percent, as it is the case for the PENALTY email, appears to be an attractive option.

\subsection{Duration of the Treatment Effect}

Having shown that receiving an email has a significant effect on behavior, we now address the question related to the duration of the effect. This is important to fully evaluate the impact of such an intervention. To this end, we partition the post-treatment period into four different time windows: (i) July 1-July 31: the effect in the first month following the first wave of emails, (ii) August 1-September 14: the time interval between a month after the first wave of emails and the beginning of the second wave, (iii) September 15-October 15: the effect one month after the second wave of emails, and (iv) after October 15

Table 7 reports the estimates for equation (1) separately for the four time windows. The upper part of Table 7 refers to treatments Control, REMinder, and Social, covering all users, while the lower part reports the results for all five treatments (restricted to previously late users only).

[Table 7 here]

The table shows that the effect of getting an email is short term, but it is replicated after getting a second email. No matter whether we use the proportion of late returns 
per user as a dependent variable, or the average number of days between the return date and the due date, the effect lasts for one month. The first emails that were sent on July 1 had an effect in the period July 1-July 31, but the effect becomes insignificant in the period August 1-September 15. The same pattern can be observed for the emails that were sent on September 15. Interestingly, users who stopped reacting to the first email react again upon reception of the second message.

\subsection{Heterogenous Treatment Effects by User Characteristics}

After estimating the average treatment effect of sending different emails, we now proceed to the analysis of heterogeneous reactions depending on relevant user-specific characteristics. We start by testing for differential treatment effects that depend on users' previous behavior in terms of late returns/days between return and due date. Afterwards, we study whether there are significant differences in behavior depending on age, gender and nationality.

\subsubsection{Previous Compliance with the Norm}

It is conceivable that the reaction to the different treatments is related to the users' compliance history, that is, their behavior prior to the treatment. To test for this, we interact the treatment variables with Prior Late and Prior "Actual-Due". Prior Late and Prior "Actual-Due" refer to the average user-specific proportion of late returns/days between return and due date in the pre-treatment period.

[Table 8 here]

Table 8 reports the results. We observe that the interaction terms are mostly negative and significant, suggesting that the less norm-compliant users were in the pre-treatment, the stronger is their reaction to the treatments. When we compare the treatments to CONTROL according to the proportion of late returns (columns (1) and (3)), we see that the REMINDER treatment has a stronger effect on those users who had a higher proportion of late returns prior to the treatment. When the treatment variables are interacted with the user-specific Prior "Actual-Due" (columns (2) and (4)), we see that the previous non-compliers have a stronger reaction to the REMINDER message, but also to the LATE and PenAlty messages. 
To summarize, the email treatments are especially effective in changing the behavior of a very relevant sample of users, namely those breaking the rule more often. Also, it is important to see that there are no crowding out effects. For users who have a value of Prior Late and Prior "Actual-Due" equal to 0, the estimated treatment effects are still negative (some of them significant), suggesting a positive effect on the "good types" as well.

\subsubsection{Age}

We now test for differential treatment effects that are related to different age groups. To this end, we reproduce the estimations of equation (1) separately for the following age groups: below 20 years of age, between 20 and 40, between 40 and 60, and above 60. Table 9 reports the results.

[Table 9 here]

When we compare Reminder and Social for all users (upper part of Table 9), we see a strong reaction to the emails coming from users in the age categories 20 to 40 and 40 to 60 . For users between 20 and 40, both emails are significant, reducing the proportion of late returns per user by around 2 percentage points and the average number of days between the return date and the due date per user by more than half a day. For users between 40 and 60, the effect of a treatment email is a reduction of the proportion of late returns by up to 2.6 percentage points, and a reduction in the average number of days between the return date and the due date of up to 0.9 days. Finally, for the youngest and oldest age groups, no significant effects are observed.

When we look at late users only (lower part of Table 9), again a strong reaction to the email treatments comes from users in the age classes 20 to 40 and 40 to 60 , at least for the proportion of late returns. Another interesting feature shown in the table is that the PenALty treatment is significant in all age groups for at least one of the two measures we look at. This shows that the PENALTy treatment is effective in all age groups. Finally, when we look at the highest age group, i.e. users above 60 , we see that when the effects are significant they become very large, reducing the proportion of late returns per user by even 10 percentage points for LATE and 8.7 percentage points for PEnalty treatments. 
In sum, interesting age patterns emerge that depend to some extent on the dependent variable used. One of the most effective emails, which seems to work independently of the age group of the late users, is the PENALTy treatment.

\subsubsection{Gender}

Whether and why gender matters has increasingly attracted economists' attention. In a recent comprehensive survey, Croson and Gneezy (2009) find that women and men differ along some dimensions (e.g. competitiveness), but not necessarily in others (social preferences revealed in lab experiments). Our data offer a rare opportunity to measure gender differences in rule compliance in daily life, and also the reaction to different email treatments. For the subsequent analysis, we construct interaction variables between our gender variable, Male, and the treatment dummy variables.

[Table 10 here]

Table 10 reports the results. As for the Male dummy, it is statistically not significant, meaning that in the control group, women and men show similar patterns in compliant behavior. ${ }^{11}$ As for the estimated interaction terms, the coefficients are (with one exception) insignificant, indicating that there are no gender differences in the reaction to the emails. In other words, both women and men are highly comparable when it comes to rule compliance and the reaction to messages aimed at promoting rule compliance.

\subsubsection{Nationality}

There is sound evidence that nationality is an important determinant of behavior in a variety of settings. Fisman and Miguel (2007), for example, show interesting nationality differences in the determinants of corruption. Our database allows us to distinguish between the users' countries of origin, and hence we can evaluate whether the behavior of users differs by nationality, and whether there are differential reactions to receiving an email based on users' nationality.

We classify users into 8 geographical areas according to their nationality: (i) Spain, (ii) Northern and Central Europe (Germany, Belgium, Denmark, Finland, Netherlands,

\footnotetext{
${ }^{11}$ We find the same result if we do not include previous compliance as a control.
} 
Norway, Sweden, Switzerland, Austria), (iii) Southern and Western Europe (France, Italy, Greece, Portugal), (iv) English speaking countries (UK, US, Canada, Ireland, and Australia), (v) Eastern Europe and Russia (Bulgaria, Croatia, Slovakia, Estonia, Hungary, Lithuania, Poland, Rumania, Russia, Czech Republic, Ukraine, Georgia, Armenia), (vi) Latin America (Argentina, Bolivia, Brazil, Colombia, Cuba, Dominican Republic, Ecuador, Guatemala, Honduras, Mexico, Nicaragua, Paraguay, Peru, El Salvador, Uruguay, Venezuela, Chile, Costa Rica, Panama), (vii) Asia (Philippines, Japan, Nepal, China, India, South Korea), and (viii) Africa (Algeria, Morocco, Senegal, Nigeria). Spain accounts for the vast majority of users (around 70\%), followed by Latin America with 17\%, Southern and Western Europe with 6\%, and at the bottom of the distribution is Asia with $0.7 \%$.

We first analyze whether foreign users differ in their proportion of late returns with respect to Spaniards. Table A.1 in the appendix reports the average user specific propensity for being late in the pre and post-treatment period by nationality groups (columns (1) and (2), respectively), where the omitted variable is Spaniards. It is clear that there are significant differences. The proportion of late returns in nationality groups (iii) to (vi) is higher than that presented by Spaniards. Users from Latin America and from the English speaking countries are among those geographical areas that show the highest differential with respect to Spaniards. On the other hand, Asian users seem to show a lower propensity for being late than Spaniards.

An interesting question is whether there are differential treatment effects that are related to different nationalities. Tables 11 reports the results on the proportion of late returns per user and on the average number of days between the return date and the due date per user for the eight nationality groups separately.

\section{[Table 11]}

There are remarkable differences. First, users from English speaking countries react significantly to every single treatment. They reduce the proportion of late returns by up to 30 percentage points and reduce the average number of days between the return date and the due date by up to 8.5 days. Previously late users from Asia also react significantly, in particular to the treatments REMinder, LATE and PENALTy. With the exception of Spain, we do not find consistent and significant effects for the other nationality groups. 
We now directly compare the effects found for Spaniards with the effects found for English speaking and Asian countries, controlling for different initial propensities of being late, as well as different reactions depending on prior propensity to be late. Given that different nationality groups show very different proportion of late returns per user, as well as a different average number of days between the return date and the due date per user, one concern might be that some nationalities react more strongly not because of the nationality but because they had a very different compliant behavior to begin with. To deal with such concern and to test for the robustness of the results, we have replicated the analysis in Tables A.2 and A.3, including interactions between prior behavior and the treatment. As can be seen from Table A.2, users coming from English speaking countries react significantly more than Spaniards, for both measures of the dependent variable. For Asian users, as shown in Table A.3, we also see that the effect is significantly higher than for Spaniards, but only for the late users and treatments REMinder and PENALTY. As such, users from English speaking countries and Asian users react strongly, despite having very different initial levels of compliance. Finally, we did a similar exercise for the other nationality groups, but we did not find significant results (all results are available upon request).

\section{Conclusions}

In this paper we study the effect of a very simple, versatile, and virtually costless mechanism, such as sending email messages, on promoting compliance with norms and rules. The study was conducted in the Public Libraries of Barcelona, where compliance with rules means returning items on time. What makes our setting unique is that we observe a large number of users in a daily-life situation, where rules are simple and welldefined, and where compliance is perfectly measurable. The users are diverse in terms of gender, age and nationality, which allows us to study different reactions depending on relevant user characteristics.

Using the methodology of a randomized field experiment, we show that sending email messages helps to promote compliance with rules. The largest effect comes from an email reminding users of the penalties associated with late returns, which decreases the proportion of late returns by 7 percent, and the average number of days between the return date and the due date by 13 percent. Yet, the effects are substantially 
bigger for certain subgroups. For instance, users with a high proportion of late returns in the pre-treatment period react more strongly than the other users do. Also, age and nationality appear to affect reactions to the messages. In contrast, and maybe somewhat surprisingly, we find no evidence for gender differences in rule compliance and in the reaction to receiving one of the email messages.

\section{References}

[1] Andreoni, James and Vesterlund, Lise (2001), "Which Is the Fair Sex? Gender Differences in Alstruism," Quarterly Journal of Economics, 116:293-312.

[2] Andreoni, James and Rao, Justin M. (2010), "The Power of Asking: How Communication Affects Selfishness, Empathy and Altruism," mimeo.

[3] Benabou, Roland and Tirole, Jean (2003), "Intrinsic and Extrinsic Motivation," Review of Economic Studies, 70:489-520.

[4] Benabou, Roland and Tirole, Jean (2006), "Incentives and Pro-Social Behavior," American Economic Review, 96(5):1652-1678.

[5] Charness, Gary and Dufwenberg, Martin (2006). "Promises and Partnership," Econometrica, 74(6):1579-1601.

[6] Charness, Gary and Dufwenberg, Martin (2010). "Participation," American Economic Review, forthcoming.

[7] Charness, Gary and Gneezy, Uri (2007), "Strong Evidence for Gender Differences in Investment," mimeo.

[8] Charness, Gary and Rustichini, Aldo (2009), "Gender Differences in Cooperation with Group Membership," mimeo.

[9] Fong, Christina and Luttmer, Erzo (2009), "What Determines Giving to Hurricane Katrina Victims? Experimental Evidence on Racial Group Loyalty," American Economic Journal: Applied Economics, 1(2):64-87. 
[10] Croson, Rachel and Buchan, Nancy (1999), "Gender and Culture: International Experimental Evidence from Trust Games," American Economic Review PEP, 89(2):386-391.

[11] Croson, Rachel and Gneezy, Uri (2009), "Gender Differences in Preferences," Journal of Economic Literature, 47(2):1-27.

[12] Dal Bó, Ernesto and Dal Bó, Pedro (2009), "Do the Right Thing: The Effect of Moral Suasion on Cooperation," mimeo.

[13] Ellingsen, Tore and Johannesson, Magnus (2004), "Promises, Threats and Fairness," Economic Journal, 114(495):397-420.

[14] Ellingsen, Tore and Johannesson, Magnus (2008), "Anticipated Verbal Feedback Induces Altruistic Behavior," Evolution and Human Behavior, 29(2):100-105.

[15] Fellner, Gerlinde, Sausgruber, Rupert and Traxler, Christian (2009), "Testing Enforcement Strategies in the Field: Legal Threat, Moral Appeal and Social Information," mimeo.

[16] Fernandez, Raquel (2007a), "Culture and Economics," Forthcoming: New Palgrave Dictionary of Economics, 2nd edition, edited by Steven N. Durlauf and Lawrence E. Blume. Palgrave Macmillan.

[17] Fernandez, Raquel (2007b), "Culture and Economics". Journal of the European Economic Association, 5(2-3):305-332.

[18] Fisman, Ray and Miguel, Edward (2007), "Corruption, Norms, and Legal Enforcement: Evidence from Diplomatic Parking Tickets," Journal of Political Economy, 115(6):1020-1048.

[19] Funk, Patricia (2010), "Social Incentives and Voter Turnout: Evidence from the Swiss Mail Voting System," Journal of the European Economic Association, forthcoming.

[20] Gächter, Simon, Herrmann, Benedikt and Thöni, Christian (2010), "Culture and Cooperation," mimeo. 
[21] Gerber, Alan S., Green, Donald P., and Larimer, Christopher W. (2008), "Social Pressure and Voter Turnout: Evidence from a Large-Scale Field Experiment," American Political Science Review, 102(1):33-48.

[22] Gneezy, Uri and Rustichini, Aldo (2000), "A Fine is a Price," Journal of Legal Studies, 29(1):1-18.

[23] Guiso, Luigi, Sapienza, Paola and Zingales, Luigi (2009), "Cultural Biases in Economic Exchange," Quarterly Journal of Economics, 124(3):1095-1131.

[24] Herrmann, Benedikt, Thöni, Christian and Gächter, Simon (2008), "Antisocial Punishment Across Societies," Science, 319:1362-1367.

[25] Levitt, Steven D. and List, John A. (2007), "What do Laboratory Experiments Measuring Social Preferences Tell Us about the Real World," Journal of Economic Perspectives, 21(2):153-174.

[26] Luttmer, Erzo F.P. and Singhal, Monica (2010), "Culture, Context, and the Taste for Redistribution," American Economic Journal: Economic Policy, forthcoming.

[27] Mellstroem, Carl and Johannesson, Magnus (2008), "Crowding Out in Blood Donation: Was Titmuss Right?" Journal of the European Economic Association, $6(4): 845-863$.

[28] Niederle, Muriel and Vesterlund, Lise (2007), "Do Women Shy Away from Competition? Do Men Compete Too Much?" Quarterly Journal of Economics, 122:10671101. 
Table 1-Email Messages

\begin{tabular}{|c|c|}
\hline E-mail & Text \\
\hline Control & $\begin{array}{l}\text { Dear User, } \\
\text { In the next webpage you will find information on the services and activities offered by the Libraries of Barcelona: } \\
\text { http://www.bcn.es/biblioteques/ } \\
\text { Best wishes, } \\
\text { Libraries of Barcelona }\end{array}$ \\
\hline $\begin{array}{l}\text { General } \\
\text { Reminder }\end{array}$ & $\begin{array}{l}\text { Dear User, } \\
\text { If at some point you borrow an item from the library, please remember that you have to return it on time. } \\
\text { Best wishes, } \\
\text { Libraries of Barcelona } \\
\text { In the next webpage you will find information on the services and activities offered by the Libraries of Barcelona: } \\
\text { http://www.bcn.es/biblioteques/ }\end{array}$ \\
\hline $\begin{array}{l}\text { Social } \\
\text { Motivation }\end{array}$ & $\begin{array}{l}\text { Dear User, } \\
\text { For a good functioning of the Public Libraries it is important to return the items that are borrowed on time. } \\
\text { Best wishes, } \\
\text { Libraries of Barcelona } \\
\text { In the next webpage you will find information on the services and activities offered by the Libraries of Barcelona: } \\
\text { http://www.bcn.es/biblioteques/ }\end{array}$ \\
\hline $\begin{array}{l}\text { Identification } \\
\text { Late }\end{array}$ & $\begin{array}{l}\text { Dear User, } \\
\text { In the last months you have returned an item late. If at some point you borrow an item from the library, please } \\
\text { remember that you have to return it on time. } \\
\text { Best wishes, } \\
\text { Libraries of Barcelona } \\
\text { In the next webpage you will find information on the services and activities offered by the Libraries of Barcelona: } \\
\text { http://www.bcn.es/biblioteques/ }\end{array}$ \\
\hline $\begin{array}{l}\text { Identification } \\
\text { Late and } \\
\text { Reminder of } \\
\text { the Penalty }\end{array}$ & $\begin{array}{l}\text { Dear User, } \\
\text { In the last months you have returned an item late. If at some point you borrow an item from the library, please } \\
\text { remember that you have to return it on time. } \\
\text { Remember that the time that a user will be excluded from the possibility of borrowing an item will be the } \\
\text { same number of natural days elapsed since the day that the item should have been returned. The maximum } \\
\text { period for exclusion is one year. } \\
\text { Best wishes, } \\
\text { Libraries of Barcelona } \\
\text { In the next webpage you will find information on the services and activities offered by the Libraries of Barcelona: } \\
\text { http://www.bcn.es/biblioteques/ }\end{array}$ \\
\hline
\end{tabular}

Notes: The text in bold refers to the new addition of the treatment email. The words in bold in the first column represent the labels we will use in the paper. 
TABLE 2

User Randomization into Treatments CONTROL-REMINDER-SOCIAL

\begin{tabular}{|c|c|c|c|c|c|c|c|c|c|c|}
\hline & \multicolumn{3}{|c|}{ CONTROL } & \multicolumn{3}{|c|}{ "REMINDER } & \multicolumn{3}{|c|}{ SOCIAL } & \multirow{2}{*}{$\begin{array}{r}\text { P-Value } \\
\text { Equ. Mean }\end{array}$} \\
\hline & Obs. & Mean & Std. Dev. & Obs. & Mean & Std. Dev. & Obs. & Mean & Std. Dev. & \\
\hline \multicolumn{11}{|c|}{ Wave 1 (Active between 1.January-5.May) } \\
\hline Male & 9438 & 0,42 & 0,49 & 9059 & 0,42 & 0,49 & 9423 & 0,42 & 0,49 & 0,67 \\
\hline Age & 9448 & 32,71 & 13,83 & 9062 & 32,76 & 13,89 & 9434 & 33,07 & 13,78 & 0,16 \\
\hline Foreign & 9467 & 0,28 & 0,45 & 9080 & 0,30 & 0,46 & 9452 & 0,30 & 0,46 & 0,07 \\
\hline Proportion Late & 9467 & 0,33 & 0,39 & 9080 & 0,33 & 0,39 & 9452 & 0,33 & 0,39 & 0,94 \\
\hline "Actual - Due" Date & 9376 & 1,74 & 16,75 & 8995 & 1,53 & 16,37 & 9349 & 1,31 & 15,86 & 0,19 \\
\hline Nr. Loans Total & 9467 & 31,51 & 53,46 & 9080 & 31,65 & 52,58 & 9452 & 32,73 & 58,33 & 0,25 \\
\hline Nr. Loans 2009 - Half 1 & 9467 & 11,92 & 18,80 & 9080 & 11,89 & 19,01 & 9452 & 12,48 & 22,21 & 0,08 \\
\hline Book & 9467 & 0,60 & 0,42 & 9080 & 0,60 & 0,42 & 9452 & 0,61 & 0,42 & 0,30 \\
\hline$C D$ & 9467 & 0,09 & 0,23 & 9080 & 0,10 & 0,23 & 9452 & 0,09 & 0,23 & 0,49 \\
\hline DVD & 9467 & 0,28 & 0,37 & 9080 & 0,28 & 0,37 & 9452 & 0,27 & 0,36 & 0,32 \\
\hline Magazine & 9467 & 0,03 & 0,13 & 9080 & 0,02 & 0,12 & 9452 & 0,02 & 0,11 & 0,12 \\
\hline Attrition & 9467 & 0,54 & 0,50 & 9080 & 0,53 & 0,50 & 9452 & 0,54 & 0,50 & 0,24 \\
\hline \multicolumn{11}{|c|}{ Wave 2 (Active between 1.March-31.July) } \\
\hline Male & 10037 & 0,42 & 0,49 & 9758 & 0,41 & 0,49 & 10151 & 0,41 & 0,49 & 0,81 \\
\hline Age & 10049 & 32,74 & 14,09 & 9763 & 32,49 & 13,98 & 10157 & 32,79 & 13,73 & 0,28 \\
\hline Foreign & 10064 & 0,28 & 0,45 & 9782 & 0,29 & 0,45 & 10180 & 0,30 & 0,46 & 0,01 \\
\hline Proportion Late & 10063 & 0,35 & 0,39 & 9782 & 0,36 & 0,39 & 10180 & 0,35 & 0,39 & 0,92 \\
\hline "Actual - Due" Date & 9923 & 1,58 & 14,69 & 9639 & 1,54 & 14,82 & 10047 & 1,48 & 14,33 & 0,89 \\
\hline Nr. Loans Total & 10064 & 30,28 & 52,25 & 9782 & 30,12 & 51,25 & 10180 & 31,40 & 56,98 & 0,18 \\
\hline Nr. Loans 2009 - Half 1 & 10064 & 11,18 & 18,56 & 9782 & 11,01 & 18,67 & 10180 & 11,67 & 21,83 & 0,05 \\
\hline Book & 10064 & 0,62 & 0,41 & 9782 & 0,62 & 0,41 & 10180 & 0,61 & 0,41 & 0,49 \\
\hline$C D$ & 10064 & 0,09 & 0,22 & 9782 & 0,09 & 0,22 & 10180 & 0,09 & 0,22 & 0,47 \\
\hline DVD & 10064 & 0,27 & 0,36 & 9782 & 0,27 & 0,36 & 10180 & 0,27 & 0,36 & 0,31 \\
\hline Magazine & 10064 & 0,03 & 0,13 & 9782 & 0,03 & 0,13 & 10180 & 0,03 & 0,12 & 0,23 \\
\hline Attrition & 10064 & 0,51 & 0,50 & 9782 & 0,51 & 0,50 & 10180 & 0,52 & 0,50 & 0,20 \\
\hline
\end{tabular}

Notes: All variables refer to all users, late and non-late, who were active in windows 1 (1 January-15 May) and 2 (1 March-31 July). All variables are obtained at the user level. Male takes a value of 1 in case of male. Age shows the user's age in years, and Foreign is a dummy variable taking a value of 1 in the case of Non-Spanish. Proportion Late measures the proportion of late returns per user, and "Actual - Due" Date measures the average number of days between the return date and the deadline per user. Number of Loans represents the number of loans per user. Book, CD, DVD and Magazine reflects the user's average share of Books, CD's, DVD's and Magazines. Attrition refers to the share of users who do not borrow/return any item after the email intervention. The $P$-Valu in the last column is for the F-Test of equality of variable means across all three groups. 
TABLE 3

User Randomization into Treatments CRONTOL-REMINDER-SOCIAL-LATE-PENALTY

\begin{tabular}{|c|c|c|c|c|c|c|c|c|c|c|c|c|c|c|c|c|}
\hline & \multicolumn{3}{|c|}{$\begin{array}{l}\text { CONTROL } \\
\end{array}$} & \multicolumn{3}{|c|}{ REMINDER } & \multicolumn{3}{|c|}{ "SOCIAL } & \multicolumn{3}{|c|}{ LATE } & \multicolumn{3}{|c|}{ PENALTY } & \multirow{2}{*}{$\begin{array}{c}\text { P-Value } \\
\text { Equ. Means }\end{array}$} \\
\hline & Obs. & Mean & Std. Dev. & Obs. & Mean & Std. Dev. & Obs. & Mean & Std. Dev. & Obs. & Mean & Std. Dev. & Obs. & Mean & Std. Dev. & \\
\hline \multicolumn{17}{|c|}{ Wave 1 (Active between 1.January-5.May) } \\
\hline Male & 4315 & 0,43 & 0,49 & 4182 & 0,43 & 0,50 & 4351 & 0,43 & 0,50 & 4333 & 0,43 & 0,50 & 4304 & 0,42 & 0,49 & 0,97 \\
\hline Age & 4321 & 32,20 & 12,78 & 4187 & 32,30 & 12,83 & 4355 & 32,48 & 12,55 & 4343 & 32,41 & 12,76 & 4312 & 32,23 & 12,58 & 0,82 \\
\hline Foreign & 4331 & 0,33 & 0,47 & 4195 & 0,35 & 0,48 & 4367 & 0,35 & 0,48 & 4355 & 0,34 & 0,48 & 4323 & 0,35 & 0,48 & 0,08 \\
\hline Proportion Late & 4331 & 0,59 & 0,33 & 4195 & 0,58 & 0,33 & 4367 & 0,59 & 0,33 & 4355 & 0,58 & 0,33 & 4323 & 0,59 & 0,33 & 0,22 \\
\hline "Actual - Due" Date & 4270 & 6,61 & 20,79 & 4143 & 5,94 & 20,42 & 4301 & 5,68 & 19,37 & 4288 & 5,91 & 19,08 & 4269 & 5,75 & 18,22 & 0,20 \\
\hline Nr. Loans Total & 4331 & 46,15 & 67,88 & 4195 & 47,52 & 67,61 & 4367 & 48,54 & 76,08 & 4355 & 47,34 & 74,48 & 4323 & 48,00 & 74,16 & 0,62 \\
\hline Nr. Loans 2009 - Half 1 & 4331 & 17,48 & 24,19 & 4195 & 17,91 & 24,63 & 4367 & 18,50 & 29,57 & 4355 & 17,88 & 25,38 & 4323 & 18,35 & 27,10 & 0,39 \\
\hline Book & 4331 & 0,50 & 0,39 & 4195 & 0,49 & 0,39 & 4367 & 0,50 & 0,39 & 4355 & 0,49 & 0,39 & 4323 & 0,48 & 0,39 & 0,20 \\
\hline$C D$ & 4331 & 0,12 & 0,24 & 4195 & 0,12 & 0,24 & 4367 & 0,12 & 0,24 & 4355 & 0,13 & 0,24 & 4323 & 0,12 & 0,24 & 0,77 \\
\hline DVD & 4331 & 0,35 & 0,36 & 4195 & 0,36 & 0,37 & 4367 & 0,35 & 0,36 & 4355 & 0,36 & 0,36 & 4323 & 0,36 & 0,36 & 0,48 \\
\hline Magazine & 4331 & 0,03 & 0,12 & 4195 & 0,03 & 0,13 & 4367 & 0,03 & 0,12 & 4355 & 0,03 & 0,12 & 4323 & 0,03 & 0,12 & 0,69 \\
\hline Attrition & 4331 & 0,48 & 0,50 & 4195 & 0,47 & 0,50 & 4367 & 0,49 & 0,50 & 4355 & 0,47 & 0,50 & | 4323 & 0,47 & 0,50 & 0,18 \\
\hline \multicolumn{17}{|c|}{ Wave 2 (Active between 1.March-31.July) } \\
\hline Male & 4069 & 0,43 & 0,49 & 4014 & 0,43 & 0,49 & 4178 & 0,42 & 0,49 & 4158 & 0,42 & 0,49 & 4060 & 0,42 & 0,49 & 0,94 \\
\hline Age & 4078 & 32,18 & 12,85 & 4019 & 31,82 & 12,74 & 4180 & 32,12 & 12,43 & 4166 & 32,31 & 12,81 & 4066 & 31,78 & 12,46 & 0,25 \\
\hline Foreign & 4086 & 0,33 & 0,47 & 4029 & 0,34 & 0,47 & 4186 & 0,36 & 0,48 & 4178 & 0,35 & 0,48 & 4077 & 0,37 & 0,48 & 0,01 \\
\hline Proportion Late & 4086 & 0,62 & 0,32 & 4029 & 0,62 & 0,32 & 4186 & 0,61 & 0,33 & 4178 & 0,61 & 0,32 & 4077 & 0,61 & 0,33 & 0,17 \\
\hline "Actual - Due" Date & 3989 & 6,55 & 17,96 & 3940 & 6,50 & 18,20 & 4108 & 6,02 & 16,93 & 4067 & 6,27 & 17,70 & 3996 & 6,23 & 16,97 & 0,65 \\
\hline Nr. Loans Total & 4086 & 46,52 & 68,75 & 4029 & 46,92 & 68,29 & 4186 & 48,43 & 76,93 & 4178 & 46,78 & 74,60 & 4077 & 47,71 & 74,96 & 0,75 \\
\hline Nr. Loans 2009 - Half 1 & 4086 & 17,51 & 24,55 & 4029 & 17,67 & 25,10 & 4186 & 18,54 & 30,35 & 4178 & 17,77 & 26,05 & 4077 & 18,38 & 27,46 & 0,32 \\
\hline Books & 4086 & 0,50 & 0,39 & 4029 & 0,49 & 0,39 & 4186 & 0,49 & 0,39 & 4178 & 0,49 & 0,39 & 4077 & 0,48 & 0,39 & 0,63 \\
\hline CDs & 4086 & 0,12 & 0,24 & 4029 & 0,11 & 0,23 & 4186 & 0,12 & 0,24 & 4178 & 0,12 & 0,24 & 4077 & 0,12 & 0,24 & 0,36 \\
\hline DVDs & 4086 & 0,35 & 0,36 & 4029 & 0,36 & 0,37 & 4186 & 0,36 & 0,36 & 4178 & 0,36 & 0,36 & 4077 & 0,36 & 0,36 & 0,74 \\
\hline Magazines & 4086 & 0,03 & 0,13 & 4029 & 0,04 & 0,14 & 4186 & 0,03 & 0,12 & 4178 & 0,03 & 0,12 & 4077 & 0,03 & 0,13 & 0,06 \\
\hline Atrition & 4086 & 0,46 & 0,50 & 4029 & 0,46 & 0,50 & 4186 & 0,48 & 0,50 & 4178 & 0,45 & 0,50 & 4077 & 0,46 & 0,50 & 0,17 \\
\hline
\end{tabular}

Notes: All variables refer to the late users who were active in windows 1 ( 1 January-15 May) and 2 ( 1 March-31 July). All variables are obtained at the user level. Male takes a value of 1 in case of male, age shows the user's age in years, and Foreign is a dummy variable taking a value of 1 in the case of Non-Spanish. Proportion Late measures the proportion of late returns per user, and "Actual - Due" Date measures the average number of days between the return date and the deadline per user. Number of Loans represents the number of loans per user. Book, CD, DVD and Magazine reflects the user's average share of Books, CD's, DVD's and Magazines. Attrition refers to the share of users who do not borrow/return any item after the email intervention. The $P$-Value in the last column is for the $\mathrm{F}$-Test of equality of variable means across all five groups. 
TABLE 4

CONTROL-REMINDER-SOCIAL

\begin{tabular}{|c|c|c|c|c|c|c|}
\hline & \multicolumn{3}{|c|}{ Proportion Late } & \multicolumn{3}{|c|}{ "Actual - Due" Date } \\
\hline & (1) & (2) & (3) & (4) & (5) & (6) \\
\hline Reminder & $\begin{array}{c}-0.0129^{\star} \\
(0.00777)\end{array}$ & $\begin{array}{l}-0.0123^{\star} \\
(0.00719)\end{array}$ & $\begin{array}{l}-0.0138^{\star} \\
(0.00715)\end{array}$ & $\begin{array}{l}-0.387^{\star} \\
(0.203)\end{array}$ & $\begin{array}{c}-0.395^{\star *} \\
(0.192)\end{array}$ & $\begin{array}{c}-0.468^{\star *} \\
(0.189)\end{array}$ \\
\hline Social & $-0.0167^{* *}$ & $-0.0160^{\star \star}$ & $-0.0184^{\star \star *}$ & -0.314 & -0.296 & $\begin{array}{l}-0.409^{\star \star} \\
(0188)\end{array}$ \\
\hline CD & & & $\begin{array}{c}0.0850^{* * *} \\
(0.0142)\end{array}$ & & & $\begin{array}{c}3.434^{* * *} \\
(0.373)\end{array}$ \\
\hline DVD & & & $\begin{array}{l}0.0924^{\star * *} \\
(0.00862)\end{array}$ & & & $\begin{array}{c}3.455^{\star \star \star} \\
(0.229)\end{array}$ \\
\hline Magazine & & & $\begin{array}{c}0.0776^{* * *} \\
(0.0225)\end{array}$ & & & $\begin{array}{c}3.734^{\star \star \star} \\
(0.600)\end{array}$ \\
\hline August & & $\begin{array}{c}0.0461^{\star * *} \\
(0.0131)\end{array}$ & $\begin{array}{c}0.0681^{* * *} \\
(0.0134)\end{array}$ & & $\begin{array}{l}-0.397 \\
(0.344)\end{array}$ & $\begin{array}{c}0.525 \\
(0.348)\end{array}$ \\
\hline September & & $\begin{array}{l}0.00603 \\
(0.0106)\end{array}$ & $\begin{array}{l}0.00730 \\
(0.0106)\end{array}$ & & $\begin{array}{c}-2.582^{\star \star *} \\
(0.278)\end{array}$ & $\begin{array}{c}-2.514^{\star * *} \\
(0.276)\end{array}$ \\
\hline October & & $\begin{array}{l}0.0303^{\star * *} \\
(0.00924)\end{array}$ & $\begin{array}{l}0.0253^{\star * *} \\
(0.00920)\end{array}$ & & $\begin{array}{c}-3.247^{\star \star *} \\
(0.248)\end{array}$ & $\begin{array}{c}-3.414^{\star * *} \\
(0.245)\end{array}$ \\
\hline November & & $\begin{array}{l}-0.391^{\star \star \star} \\
(0.0205)\end{array}$ & $\begin{array}{c}-0.375^{\star \star \star} \\
(0.0204)\end{array}$ & & $\begin{array}{c}-12.74^{\star \star \star} \\
(0.545)\end{array}$ & $\begin{array}{c}-11.91^{\star \star *} \\
(0.540)\end{array}$ \\
\hline Age $20-40$ & & $\begin{array}{c}0.00709 \\
(0.00894)\end{array}$ & $\begin{array}{l}-0.00423 \\
(0.00897)\end{array}$ & & $\begin{array}{c}0.372 \\
(0.240)\end{array}$ & $\begin{array}{c}0.00343 \\
(0.238)\end{array}$ \\
\hline Age $40-60$ & & $\begin{array}{r}-0.0549^{* * *} \\
(0.00996)\end{array}$ & $\begin{array}{c}-0.0610^{\star * *} \\
(0.00996)\end{array}$ & & $\begin{array}{c}-0.976^{\star \star \star} \\
(0.266)\end{array}$ & $\begin{array}{c}-1.172^{* * *} \\
(0.263)\end{array}$ \\
\hline Age over 60 & & $\begin{array}{l}-0.105^{\star \star \star} \\
(0.0159)\end{array}$ & $\begin{array}{c}-0.104^{\star * \star} \\
(0.0159)\end{array}$ & & $\begin{array}{c}-1.748^{\star \star *} \\
(0.420)\end{array}$ & $\begin{array}{c}-1.620^{\star \star *} \\
(0.416)\end{array}$ \\
\hline Male & & $\begin{array}{c}0.00540 \\
(0.00596)\end{array}$ & $\begin{array}{l}-0.00146 \\
(0.00597)\end{array}$ & & $\begin{array}{l}0.0573 \\
(0.159)\end{array}$ & $\begin{array}{l}-0.225 \\
(0.157)\end{array}$ \\
\hline Foreign & & $\begin{array}{l}0.0454^{\star * *} \\
(0.00676)\end{array}$ & $\begin{array}{l}0.0328^{* * *} \\
(0.00684)\end{array}$ & & $\begin{array}{c}1.141^{\star \star *} \\
(0.180)\end{array}$ & $\begin{array}{c}0.683^{* \star *} \\
(0.181)\end{array}$ \\
\hline Number of Loans & & $\begin{array}{c}-0.00256^{* * *} \\
(0.000199)\end{array}$ & $\begin{array}{c}-0.00321^{\star * *} \\
(0.000209)\end{array}$ & & $\begin{array}{c}-0.0443^{\star * *} \\
(0.00524)\end{array}$ & $\begin{array}{c}-0.0698^{\star * *} \\
(0.00546)\end{array}$ \\
\hline Prior Late & & $\begin{array}{c}0.331^{* * *} \\
(0.00883)\end{array}$ & $\begin{array}{c}0.317^{\star \star *} \\
(0.00884)\end{array}$ & & & \\
\hline Prior "Actual - Due" & & & & & $\begin{array}{c}0.227^{\star * *} \\
(0.00956)\end{array}$ & $\begin{array}{c}0.201^{* * *} \\
(0.00950)\end{array}$ \\
\hline Constant & $\begin{array}{c}0.358^{\star \star \star} \\
(0.00546)\end{array}$ & $\begin{array}{l}0.276^{\star \star \star} \\
(0.0114)\end{array}$ & $\begin{array}{c}0.379^{\star \star \star} \\
(0.146)\end{array}$ & $\begin{array}{c}-0.583^{\star \star \star} \\
(0.143)\end{array}$ & $\begin{array}{c}1.963^{\star \star \star} \\
(0.294)\end{array}$ & $\begin{array}{c}4.803 \\
(4.105)\end{array}$ \\
\hline Library FE & NO & NO & YES & NO & NO & YES \\
\hline $\begin{array}{l}\text { R-squared } \\
\text { number of users }\end{array}$ & $\begin{array}{r}0.000 \\
14605\end{array}$ & $\begin{array}{l}0.152 \\
14442\end{array}$ & $\begin{array}{l}0.166 \\
14442\end{array}$ & 0.000 & 0.107 & 0.138 \\
\hline$\frac{\text { Number of users }}{\text { Notes: Proportion Late } \mathrm{m}}$ & 14605 & 14442 & 14442 & 14157 & 13990 & 13990 \\
\hline \multicolumn{7}{|c|}{$\begin{array}{l}\text { Notes: Proportion Late measures the proportion of late returns per user, columns (1)-(2)-(3), and "Actual- Due" Date } \\
\text { measures the average number of days between the return date and the due date per user, columns (4)-(5)-(6). See } \\
\text { different email messages in Table } 1 . C D, D V D \text { and Magazine are dummy variables for the item type (omitted category: } \\
\text { Book), August, September, October, November months dummies (omitted category: July), and Age } 20-40 \text {, Age } 40-60 \\
\text { and Age over } 60 \text { are age dummies (omitted category: Age under } 20 \text { ). Male takes a value of } 1 \text { in case of male, Foreign a } \\
\text { value of } 1 \text { in case of non-Spanish, and Number of Loans is the average number of loans per user. Prior Late and Prior } \\
\text { "Actual - Due" refer to proportion of late returns per user and the average number of days between the return date and } \\
\text { the due date, both prior to the treatment. Robust standard errors in paranthesis. *: significant at the } 10 \% \text { level; **: } \\
\text { significant at the } 5 \% \text { level; ***: significant at the } 1 \% \text { level. }\end{array}$} \\
\hline
\end{tabular}


TABLE 5

CONTROL-REMINDER-SOCIAL-LATE-PENALTY

\begin{tabular}{|c|c|c|c|c|c|c|}
\hline & \multicolumn{3}{|c|}{ Proportion Late } & \multicolumn{3}{|c|}{ "Actual - Due" Date } \\
\hline & (1) & (2) & (3) & (4) & (5) & (6) \\
\hline Reminder & $\begin{array}{c}-0.0266^{\star *} \\
(0.0109)\end{array}$ & $\begin{array}{l}-0.0235^{\star \star} \\
(0.0102)\end{array}$ & $\begin{array}{c}-0.0239^{\star *} \\
(0.0101)\end{array}$ & $\begin{array}{l}-0.535^{\star} \\
(0.297)\end{array}$ & $\begin{array}{l}-0.565^{\star \star} \\
(0.281)\end{array}$ & $\begin{array}{l}-0.614^{\star \star} \\
(0.276)\end{array}$ \\
\hline Social & $\begin{array}{c}-0.0275^{\star \star} \\
(0.0109)\end{array}$ & $\begin{array}{c}-0.0270^{\star \star *} \\
(0.0101)\end{array}$ & $\begin{array}{c}-0.0297^{\star \star \star} \\
(0.0100)\end{array}$ & $\begin{array}{l}-0.402 \\
(0.295)\end{array}$ & $\begin{array}{l}-0.425 \\
(0.279)\end{array}$ & $\begin{array}{c}-0.549^{\star \star} \\
(0.275)\end{array}$ \\
\hline Late & $\begin{array}{c}-0.0252^{\star \star} \\
(0.0108)\end{array}$ & $\begin{array}{c}-0.0274^{\star \star \star} \\
(0.0100)\end{array}$ & $\begin{array}{c}-0.0271^{\star \star \star} \\
(0.00994)\end{array}$ & $\begin{array}{l}-0.423 \\
(0.293)\end{array}$ & $\begin{array}{l}-0.496^{*} \\
(0.278)\end{array}$ & $\begin{array}{c}-0.549^{\star *} \\
(0.273)\end{array}$ \\
\hline Penalty & $\begin{array}{c}-0.0391^{\star \star \star *} \\
(0.0108)\end{array}$ & $\begin{array}{c}-0.0409^{\star * *} \\
(0.0101)\end{array}$ & $\begin{array}{c}-0.0433^{\star \star *} \\
(0.00997)\end{array}$ & $\begin{array}{l}-0.674^{\star \star} \\
(0.294)\end{array}$ & $\begin{array}{c}-0.781^{\star \star *} \\
(0.279)\end{array}$ & $\begin{array}{c}-0.879^{\star \star \star} \\
(0.274)\end{array}$ \\
\hline CD & & & $\begin{array}{c}0.0863^{\star \star \star} \\
(0.0149)\end{array}$ & & & $\begin{array}{l}3.100^{* * *} \\
(0.405)\end{array}$ \\
\hline DVD & & & $\begin{array}{c}0.109^{\star \star \star} \\
(0.00930)\end{array}$ & & & $\begin{array}{c}3.173^{\star \star \star} \\
(0.257)\end{array}$ \\
\hline Magazine & & & $\begin{array}{l}0.109^{\star \star \star} \\
(0.0236)\end{array}$ & & & $\begin{array}{l}3.175^{\star \star \star} \\
(0.654)\end{array}$ \\
\hline August & & $\begin{array}{l}0.0261^{*} \\
(0.0145)\end{array}$ & $\begin{array}{c}0.0508^{\star * *} \\
(0.0148)\end{array}$ & & $\begin{array}{l}-0.528 \\
(0.393)\end{array}$ & $\begin{array}{c}0.542 \\
(0.399)\end{array}$ \\
\hline September & & $\begin{array}{l}0.0251^{\star *} \\
(0.0120)\end{array}$ & $\begin{array}{l}0.0212^{*} \\
(0.0120)\end{array}$ & & $\begin{array}{c}-2.576^{\star \star *} \\
(0.326)\end{array}$ & $\begin{array}{c}-2.629^{* \star *} \\
(0.323)\end{array}$ \\
\hline October & & $\begin{array}{c}0.0392^{\star * *} \\
(0.0104)\end{array}$ & $\begin{array}{c}0.0316^{* * *} \\
(0.0104)\end{array}$ & & $\begin{array}{c}-3.874^{\star * *} \\
(0.291)\end{array}$ & $\begin{array}{c}-4.124^{\star \star *} \\
(0.287)\end{array}$ \\
\hline November & & $\begin{array}{c}-0.518^{* * *} \\
(0.0244)\end{array}$ & $\begin{array}{l}-0.502^{* * *} \\
(0.0242)\end{array}$ & & $\begin{array}{c}-15.40^{\star * *} \\
(0.683)\end{array}$ & $\begin{array}{c}-14.69^{\star * \star} \\
(0.675)\end{array}$ \\
\hline Age $20-40$ & & $\begin{array}{c}0.0138 \\
(0.0103)\end{array}$ & $\begin{array}{l}-0.00112 \\
(0.0103)\end{array}$ & & $\begin{array}{c}0.944^{\star \star \star} \\
(0.288)\end{array}$ & $\begin{array}{l}0.515^{\star} \\
(0.286)\end{array}$ \\
\hline Age $40-60$ & & $\begin{array}{c}-0.0461^{\star * *} \\
(0.0117)\end{array}$ & $\begin{array}{c}-0.0549^{* * *} \\
(0.0117)\end{array}$ & & $\begin{array}{l}-0.512 \\
(0.325)\end{array}$ & $\begin{array}{c}-0.786^{\star \star} \\
(0.321)\end{array}$ \\
\hline Age over 60 & & $\begin{array}{c}-0.0832^{* * *} \\
(0.0198)\end{array}$ & $\begin{array}{c}-0.0843^{* * *} \\
(0.0197)\end{array}$ & & $\begin{array}{l}-0.754 \\
(0.543)\end{array}$ & $\begin{array}{l}-0.727 \\
(0.536)\end{array}$ \\
\hline Male & & $\begin{array}{c}0.00577 \\
(0.00647)\end{array}$ & $\begin{array}{l}-0.00151 \\
(0.00646)\end{array}$ & & $\begin{array}{c}0.106 \\
(0.179)\end{array}$ & $\begin{array}{l}-0.139 \\
(0.177)\end{array}$ \\
\hline Foreign & & $\begin{array}{l}0.0496^{\star * *} \\
(0.00700)\end{array}$ & $\begin{array}{l}0.0377^{\star * *} \\
(0.00706)\end{array}$ & & $\begin{array}{l}1.078^{* \star *} \\
(0.194)\end{array}$ & $\begin{array}{c}0.719^{* \star \star} \\
(0.194)\end{array}$ \\
\hline Number of Loans & & $\begin{array}{l}-0.00240^{* * *} \\
(0.000191)\end{array}$ & $\begin{array}{l}-0.00298^{* * *} \\
(0.000200)\end{array}$ & & $\begin{array}{r}-0.0539^{* * *} \\
(0.00511)\end{array}$ & $\begin{array}{r}-0.0727^{\star * \star} \\
(0.00533)\end{array}$ \\
\hline Prior Late & & $\begin{array}{l}0.301^{* * *} \\
(0.0109)\end{array}$ & $\begin{array}{l}0.293^{\star * \star} \\
(0.0108)\end{array}$ & & & \\
\hline Prior "Actual - Due" & & & & & $\begin{array}{c}0.170^{* * *} \\
(0.00969)\end{array}$ & $\begin{array}{c}0.156^{* * *} \\
(0.00957)\end{array}$ \\
\hline Constant & $\begin{array}{c}0.440^{\star * *} \\
(0.00769)\end{array}$ & $\begin{array}{l}0.301^{\star * *} \\
(0.0145)\end{array}$ & $\begin{array}{c}0.158 \\
(0.150)\end{array}$ & $\begin{array}{c}0.759^{\star * \star} \\
(0.209)\end{array}$ & $\begin{array}{c}2.689^{\star \star \star} \\
(0.369)\end{array}$ & $\begin{array}{c}4.478 \\
(3.690)\end{array}$ \\
\hline Library FE & NO & NO & YES & NO & NO & YES \\
\hline $\begin{array}{l}\text { R-squared } \\
\text { Number of users }\end{array}$ & $\begin{array}{c}0.001 \\
12286\end{array}$ & $\begin{array}{c}0.141 \\
12205\end{array}$ & $\begin{array}{l}0.161 \\
12205\end{array}$ & $\begin{array}{c}0.000 \\
11846\end{array}$ & $\begin{array}{c}0.101 \\
11750\end{array}$ & $\begin{array}{l}0.135 \\
11750\end{array}$ \\
\hline
\end{tabular}

Notes: Proportion Late measures the proportion of late returns per user, columns (1)-(2)-(3), and "Actual - Due" Date measures the average number of days between the return date and the due date per user, columns (4)-(5)(6). See different email messages in Table 1. CD, DVD and Magazine are dummy variables for the item type (omitted category: Book), August, September, October, November months dummies (omitted category: July), and Age 20-40, Age 40-60 and Age over 60 are age dummies (omitted category: Age under 20). Male takes a value of 1 in case of male, Foreign a value of 1 in case of non-Spanish, and Number of Loans is the average number of loans per user. Prior Late and Prior "Actual - Due" refer to proportion of late returns per user and the average number of days between the return date and the due date, both prior to the treatment. Robust standard errors in paranthesis. ${ }^{*}$ : significant at the $10 \%$ level; ${ }^{* *}$ : significant at the $5 \%$ level; ${ }^{* *}$ : significant at the $1 \%$ level. 
TABLE 6

Differential Treatment Effect with respect to the Proportion of Pending Items

\begin{tabular}{|c|c|c|c|c|}
\hline & \multicolumn{2}{|c|}{ "Control-Reminder-Social } & \multicolumn{2}{|c|}{ "Control-Reminder-Social-Late-Penalty } \\
\hline & $\begin{array}{c}\text { Prop. Late } \\
(1)\end{array}$ & $\begin{array}{c}\text { "Actual - Due" Date } \\
(2)\end{array}$ & $\begin{array}{c}\text { Prop. Late } \\
\text { (3) }\end{array}$ & $\begin{array}{c}\text { "Actual - Due" Date } \\
(4)\end{array}$ \\
\hline Reminder & $\begin{array}{l}-0.00890 \\
(0.00924)\end{array}$ & $\begin{array}{l}0.00583 \\
(0.238)\end{array}$ & $\begin{array}{l}-0.0182 \\
(0.0131)\end{array}$ & $\begin{array}{l}-0.0522 \\
(0.353)\end{array}$ \\
\hline Social & $\begin{array}{c}-0.0111 \\
(0.00915)\end{array}$ & $\begin{array}{c}0.229 \\
(0.236)\end{array}$ & $\begin{array}{c}-0.0307^{\star \star} \\
(0.0131)\end{array}$ & $\begin{array}{c}0.139 \\
(0.350)\end{array}$ \\
\hline Late & & & $\begin{array}{l}-0.0231^{*} \\
(0.0129)\end{array}$ & $\begin{array}{c}0.111 \\
(0.346)\end{array}$ \\
\hline Penalty & & & $\begin{array}{l}-0.0334^{\star *} \\
(0.0130)\end{array}$ & $\begin{array}{l}-0.349 \\
(0.350)\end{array}$ \\
\hline Pending & $\begin{array}{l}0.249^{* * *} \\
(0.0142)\end{array}$ & $\begin{array}{c}8.985^{\star * \star} \\
(0.369)\end{array}$ & $\begin{array}{l}0.267^{\star \star *} \\
(0.0202)\end{array}$ & $\begin{array}{c}10.16^{* * *} \\
(0.548)\end{array}$ \\
\hline Reminder*Pending & $\begin{array}{l}-0.00897 \\
(0.0190)\end{array}$ & $\begin{array}{c}-1.288^{\star \star *} \\
(0.494)\end{array}$ & $\begin{array}{l}-0.0151 \\
(0.0278)\end{array}$ & $\begin{array}{c}-1.718^{\star \star} \\
(0.752)\end{array}$ \\
\hline Social ${ }^{\star}$ Pending & $\begin{array}{l}-0.0161 \\
(0.0190)\end{array}$ & $\begin{array}{c}-1.826^{\star * *} \\
(0.494)\end{array}$ & $\begin{array}{c}0.000548 \\
(0.0276)\end{array}$ & $\begin{array}{c}-2.334^{\star \star \star} \\
(0.748)\end{array}$ \\
\hline Late*Pending & & & $\begin{array}{l}-0.00523 \\
(0.0273)\end{array}$ & $\begin{array}{l}-1.891^{* *} \\
(0.741)\end{array}$ \\
\hline PenaltyPending & & & $\begin{array}{l}-0.0350 \\
(0.0273)\end{array}$ & $\begin{array}{c}-1.844^{\star \star} \\
(0.741)\end{array}$ \\
\hline Constant & $\begin{array}{c}0.200 \\
(0.143)\end{array}$ & $\begin{array}{l}-1.347 \\
(3.952)\end{array}$ & $\begin{array}{l}-0.0436 \\
(0.147)\end{array}$ & $\begin{array}{l}-3.085 \\
(3.558)\end{array}$ \\
\hline Controls & YES & YES & YES & YES \\
\hline Library FE & YES & YES & YES & YES \\
\hline $\begin{array}{l}\text { R-squared } \\
\text { Number of users }\end{array}$ & $\begin{array}{l}0.204 \\
14442\end{array}$ & $\begin{array}{l}0.203 \\
13990\end{array}$ & $\begin{array}{l}0.201 \\
12205\end{array}$ & $\begin{array}{l}0.200 \\
11750\end{array}$ \\
\hline
\end{tabular}

Notes: This table reports differential treatment effects with respect to the proportion of pending items per user. Pending measures the proportion of pending items per user on the moment the email treatment is received, while the interaction terms measure the differential treatment effects of the proportion of pending items. The full set of controls is used, as well as the library fixed effects. See the notes from previous tables. Robust standard errors in paranthesis. *: significant at the $10 \%$ level; ${ }^{* *}$ : significant at the $5 \%$ level; ${ }^{* * *}$ : significant at the $1 \%$ level. 
TABLE 7

Treatment Effects over Time

\begin{tabular}{|c|c|c|c|c|c|c|c|c|}
\hline & \multicolumn{4}{|c|}{$\begin{array}{ll}\text { Proportion Late } \\
\end{array}$} & \multicolumn{4}{|c|}{ "Actual - Due" Date } \\
\hline & $\begin{array}{c}\text { July } \mathbf{1} \text { - July } \mathbf{3 1} \\
(1)\end{array}$ & $\begin{array}{c}\text { August } \mathbf{1} \text { - Sept. } 14 \\
(2)\end{array}$ & $\begin{array}{c}\text { Sept. 15-Oct. } 15 \\
(3)\end{array}$ & $\begin{array}{c}\text { Oct. } 15 \text { onwards } \\
(4)\end{array}$ & $\begin{array}{c}\text { July } \mathbf{1} \text { - July } \mathbf{3 1} \\
(5) \\
\end{array}$ & $\begin{array}{c}\text { August } \mathbf{1} \text { - Sept. } 14 \\
(6)\end{array}$ & $\begin{array}{c}\text { Sept. 15-Oct. } 15 \\
(7)\end{array}$ & $\begin{array}{c}\text { Oct. } 15 \text { onwards } \\
(8)\end{array}$ \\
\hline Reminder & $\begin{array}{c}-0.0290^{\star \star \star} \\
(0.0112)\end{array}$ & $\begin{array}{l}-0.00818 \\
(0.0129)\end{array}$ & $\begin{array}{l}-0.0108 \\
(0.0110)\end{array}$ & $\begin{array}{l}-0.0150 \\
(0.0119)\end{array}$ & $\begin{array}{c}-0.815^{\star \star} \\
(0.343)\end{array}$ & $\begin{array}{c}-0.0563 \\
(0.333)\end{array}$ & $\begin{array}{c}-0.365^{\star \star} \\
(0.182)\end{array}$ & $\begin{array}{l}-0.225 \\
(0.189)\end{array}$ \\
\hline Social & $\begin{array}{l}-0.0236^{\star *} \\
(0.0111)\end{array}$ & $\begin{array}{l}-0.00554 \\
(0.0128)\end{array}$ & $\begin{array}{l}-0.0235^{\star \star} \\
(0.0109)\end{array}$ & $\begin{array}{l}-0.00744 \\
(0.0118)\end{array}$ & $\begin{array}{c}-0.882^{\star * *} \\
(0.341)\end{array}$ & $\begin{array}{l}0.210 \\
(0.329)\end{array}$ & $\begin{array}{c}-0.543^{\star \star \star *} \\
(0.180)\end{array}$ & $\begin{array}{l}-0.283 \\
(0.187)\end{array}$ \\
\hline Constant & $\begin{array}{l}0.264^{*} \\
(0.147)\end{array}$ & $\begin{array}{c}0.776^{\star \star *} \\
(0.222)\end{array}$ & $\begin{array}{l}0.837^{\star * *} \\
(0.280)\end{array}$ & $\begin{array}{l}-0.260 \\
(0.386)\end{array}$ & $\begin{array}{l}17.82^{* * *} \\
(4.497)\end{array}$ & $\begin{array}{c}8.019 \\
(5.685)\end{array}$ & $\begin{array}{l}-7.399 \\
(9.633)\end{array}$ & $\begin{array}{l}-11.03^{*} \\
(5.820)\end{array}$ \\
\hline $\begin{array}{l}\text { Controls } \\
\text { Library FE }\end{array}$ & $\begin{array}{l}\text { YES } \\
\text { YES }\end{array}$ & $\begin{array}{l}\text { YES } \\
\text { YES }\end{array}$ & $\begin{array}{l}\text { YES } \\
\text { YES }\end{array}$ & $\begin{array}{l}\text { YES } \\
\text { YES }\end{array}$ & $\begin{array}{l}\text { YES } \\
\text { YES }\end{array}$ & $\begin{array}{l}\text { YES } \\
\text { YES }\end{array}$ & $\begin{array}{l}\text { YES } \\
\text { YES }\end{array}$ & $\begin{array}{l}\text { YES } \\
\text { YES }\end{array}$ \\
\hline $\begin{array}{l}\text { R-squared } \\
\text { Number of users }\end{array}$ & $\begin{array}{l}0.132 \\
7029 \\
\end{array}$ & $\begin{array}{l}0.129 \\
5569 \\
\end{array}$ & $\begin{array}{l}0.146 \\
7379 \\
\end{array}$ & $\begin{array}{l}0.116 \\
6340 \\
\end{array}$ & $\begin{array}{l}0.128 \\
6934 \\
\end{array}$ & $\begin{array}{l}0.151 \\
5485 \\
\end{array}$ & $\begin{array}{l}0.187 \\
7200 \\
\end{array}$ & $\begin{array}{l}0.177 \\
5797 \\
\end{array}$ \\
\hline Reminder & $\begin{array}{c}-0.0617^{\star \star \star} \\
(0.0152)\end{array}$ & $\begin{array}{l}-0.0117 \\
(0.0172)\end{array}$ & $\begin{array}{l}-0.0296^{*} \\
(0.0155)\end{array}$ & $\begin{array}{l}-0.0135 \\
(0.0168)\end{array}$ & $\begin{array}{c}-1.337^{\star \star \star} \\
(0.476)\end{array}$ & $\begin{array}{c}-0.0695 \\
(0.449)\end{array}$ & $\begin{array}{c}-0.583^{\star \star} \\
(0.252)\end{array}$ & $\begin{array}{l}-0.418 \\
(0.265)\end{array}$ \\
\hline Social & $\begin{array}{c}-0.0454^{\star \star * *} \\
(0.0153)\end{array}$ & $\begin{array}{c}0.000166 \\
(0.0170)\end{array}$ & $\begin{array}{l}-0.0224 \\
(0.0153)\end{array}$ & $\begin{array}{l}-0.0227 \\
(0.0167)\end{array}$ & $\begin{array}{c}-1.316^{\star \star *} \\
(0.481)\end{array}$ & $\begin{array}{l}0.166 \\
(0.444)\end{array}$ & $\begin{array}{l}-0.611^{\star *} \\
(0.248)\end{array}$ & $\begin{array}{l}-0.443^{*} \\
(0.263)\end{array}$ \\
\hline Late & $\begin{array}{c}-0.0389^{* *} \\
(0.0152)\end{array}$ & $\begin{array}{l}-0.0208 \\
(0.0171)\end{array}$ & $\begin{array}{c}-0.0378^{\star \star} \\
(0.0156)\end{array}$ & $\begin{array}{l}-0.0122 \\
(0.0170)\end{array}$ & $\begin{array}{l}-0.615 \\
(0.478)\end{array}$ & $\begin{array}{l}-0.496 \\
(0.445)\end{array}$ & $\begin{array}{c}-0.815^{\star \star *} \\
(0.253)\end{array}$ & $\begin{array}{l}-0.375 \\
(0.267)\end{array}$ \\
\hline Penalty & $\begin{array}{c}-0.0754^{\star \star \star *} \\
(0.0152)\end{array}$ & $\begin{array}{l}-0.0115 \\
(0.0170)\end{array}$ & $\begin{array}{l}-0.0288^{*} \\
(0.0157)\end{array}$ & $\begin{array}{l}-0.0337^{*} \\
(0.0172)\end{array}$ & $\begin{array}{c}-1.414^{* \star *} \\
(0.477)\end{array}$ & $\begin{array}{l}-0.377 \\
(0.444)\end{array}$ & $\begin{array}{c}-0.809^{* \star *} \\
(0.255)\end{array}$ & $\begin{array}{l}0.0231 \\
(0.269)\end{array}$ \\
\hline Constant & $\begin{array}{l}0.372^{\star \star \star} \\
(0.123)\end{array}$ & $\begin{array}{l}0.428^{\star *} \\
(0.189)\end{array}$ & $\begin{array}{l}0.0785 \\
(0.265)\end{array}$ & $\begin{array}{l}-0.275 \\
(0.397)\end{array}$ & $\begin{array}{l}21.67^{\star \star *} \\
(4.018)\end{array}$ & $\begin{array}{c}6.719 \\
(4.861)\end{array}$ & $\begin{array}{l}-8.824^{*} \\
(4.735)\end{array}$ & $\begin{array}{l}-11.05^{\star} \\
(5.897)\end{array}$ \\
\hline $\begin{array}{l}\text { Controls } \\
\text { Library FE }\end{array}$ & $\begin{array}{l}\text { YES } \\
\text { YES }\end{array}$ & $\begin{array}{l}\text { YES } \\
\text { YES }\end{array}$ & $\begin{array}{l}\text { YES } \\
\text { YES }\end{array}$ & $\begin{array}{l}\text { YES } \\
\text { YES }\end{array}$ & $\begin{array}{l}\text { YES } \\
\text { YES }\end{array}$ & $\begin{array}{l}\text { YES } \\
\text { YES }\end{array}$ & $\begin{array}{l}\text { YES } \\
\text { YES }\end{array}$ & $\begin{array}{l}\text { YES } \\
\text { YES }\end{array}$ \\
\hline $\begin{array}{l}\text { R-squared } \\
\text { Number of users }\end{array}$ & $\begin{array}{l}0.123 \\
6466\end{array}$ & $\begin{array}{l}0.126 \\
5294\end{array}$ & $\begin{array}{l}0.129 \\
6385\end{array}$ & $\begin{array}{l}0.117 \\
5457\end{array}$ & $\begin{array}{l}0.132 \\
6372\end{array}$ & $\begin{array}{l}0.157 \\
5205\end{array}$ & $\begin{array}{l}0.169 \\
6202\end{array}$ & $\begin{array}{l}0.182 \\
4907\end{array}$ \\
\hline
\end{tabular}


TABLE 8

Differential Treatment Effect with respect to Prior Compliance

\begin{tabular}{|c|c|c|c|c|}
\hline & \multicolumn{2}{|c|}{ "Control-Reminder-Social } & \multicolumn{2}{|c|}{ Control-Reminder-Social-Late-Penalty } \\
\hline & $\begin{array}{c}\text { Prop. Late } \\
\text { (1) }\end{array}$ & $\begin{array}{c}\text { "Actual - Due" Date } \\
(2)\end{array}$ & $\begin{array}{l}\text { Prop. Late } \\
\text { (3) }\end{array}$ & $\begin{array}{c}\text { "Actual - Due" Date } \\
(4)\end{array}$ \\
\hline Reminder & $\begin{array}{l}-0.00243 \\
(0.00981)\end{array}$ & $\begin{array}{l}-0.516^{\star \star \star} \\
(0.189)\end{array}$ & $\begin{array}{l}0.00488 \\
(0.0193)\end{array}$ & $\begin{array}{l}-0.381 \\
(0.282)\end{array}$ \\
\hline Social & $\begin{array}{c}-0.0137 \\
(0.00973)\end{array}$ & $\begin{array}{l}-0.401^{\star *} \\
(0.188)\end{array}$ & $\begin{array}{l}-0.0260 \\
(0.0193)\end{array}$ & $\begin{array}{l}-0.450 \\
(0.281)\end{array}$ \\
\hline Late & & & $\begin{array}{l}-0.0321^{\star} \\
(0.0191)\end{array}$ & $\begin{array}{l}-0.414 \\
(0.279)\end{array}$ \\
\hline Penalty & & & $\begin{array}{l}-0.0347^{\star} \\
(0.0191)\end{array}$ & $\begin{array}{l}-0.705^{\star \star} \\
(0.281)\end{array}$ \\
\hline Prior Late & $\begin{array}{l}0.334^{\star \star \star} \\
(0.0149)\end{array}$ & & $\begin{array}{l}0.307^{\star \star \star} \\
(0.0234)\end{array}$ & \\
\hline Reminder*Prior Late & $\begin{array}{l}-0.0358^{\star} \\
(0.0212)\end{array}$ & & $\begin{array}{l}-0.0581^{\star} \\
(0.0331)\end{array}$ & \\
\hline Social`Prior Late & $\begin{array}{l}-0.0146 \\
(0.0210)\end{array}$ & & $\begin{array}{l}-0.00728 \\
(0.0328)\end{array}$ & \\
\hline Late*Prior Late & & & $\begin{array}{c}0.0100 \\
(0.0325)\end{array}$ & \\
\hline Penalty*Prior Late & & & $\begin{array}{l}-0.0170 \\
(0.0323)\end{array}$ & \\
\hline Prior "Actual - Due" & & $\begin{array}{l}0.231^{\star \star \star} \\
(0.0167)\end{array}$ & & $\begin{array}{l}0.230^{\star \star \star} \\
(0.0231)\end{array}$ \\
\hline Reminder*Prior "Actual - Due" & & $\begin{array}{l}-0.0826^{\star \star *} \\
(0.0223)\end{array}$ & & $\begin{array}{l}-0.124^{\star \star \star} \\
(0.0296)\end{array}$ \\
\hline Social*Prior "Actual - Due" & & $\begin{array}{l}0.00652 \\
(0.0237)\end{array}$ & & $\begin{array}{l}-0.0519 \\
(0.0320)\end{array}$ \\
\hline $\begin{array}{l}\text { Late`Prior "Actual - Due" } \\
\text { PenaltyPrior "Actual - Due" }\end{array}$ & & & & $\begin{array}{l}-0.0715^{\star \star} \\
(0.0302) \\
-0.0910^{\star \star \star} \\
(0.0319)\end{array}$ \\
\hline Constant & $\begin{array}{l}0.375^{\star *} \\
(0.146)\end{array}$ & $\begin{array}{c}4.878 \\
(4.102)\end{array}$ & $\begin{array}{c}0.157 \\
(0.151)\end{array}$ & $\begin{array}{c}4.410 \\
(3.688)\end{array}$ \\
\hline $\begin{array}{l}\text { Controls } \\
\text { Library FE }\end{array}$ & $\begin{array}{l}\text { YES } \\
\text { YES }\end{array}$ & $\begin{array}{l}\text { YES } \\
\text { YES }\end{array}$ & $\begin{array}{l}\text { YES } \\
\text { YES }\end{array}$ & $\begin{array}{l}\text { YES } \\
\text { YES }\end{array}$ \\
\hline $\begin{array}{l}\text { R-squared } \\
\text { Number of users }\end{array}$ & $\begin{array}{r}0.166 \\
14442 \\
\end{array}$ & $\begin{array}{r}0.139 \\
13990 \\
\end{array}$ & $\begin{array}{l}0.162 \\
12205 \\
\end{array}$ & $\begin{array}{l}0.136 \\
11750 \\
\end{array}$ \\
\hline
\end{tabular}

Notes: This table reports differential treatment effects with respect to prior compliance. Prior Late measures the user-specific proportion of items that were returned late in the pre treatment period. Prior "Actual - Due" measures the average number of days between the return date and the due date per user in the pre treatment period. The full set of controls is used, as well as the library fixed effects. See the notes from previous tables. Robust standard errors in paranthesis. *: significant at the $10 \%$ level; **: significant at the $5 \%$ level; ${ }^{* *}$ : significant at the $1 \%$ level. 
TABLE 9

Treatment Effects by Age Groups

\begin{tabular}{|c|c|c|c|c|c|c|c|c|}
\hline & \multicolumn{2}{|c|}{ Age under 20} & \multicolumn{2}{|r|}{ Age 20-40 } & \multicolumn{2}{|r|}{ Age 40-60 } & \multicolumn{2}{|c|}{ Age over 60} \\
\hline & $\begin{array}{l}\text { Prop. Late } \\
\text { (1) }\end{array}$ & $\begin{array}{c}\text { "Actual - Due" Date } \\
\text { (2) }\end{array}$ & $\begin{array}{l}\text { Prop. Late } \\
\text { (3) }\end{array}$ & $\begin{array}{c}\text { "Actual - Due" Date } \\
(4)\end{array}$ & $\begin{array}{c}\text { Prop. Late } \\
\text { (5) } \\
\end{array}$ & $\begin{array}{c}\text { "Actual - Due" Date } \\
(6)\end{array}$ & $\begin{array}{l}\text { Prop. Late } \\
\text { (7) }\end{array}$ & $\begin{array}{c}\text { "Actual - Due" Date } \\
(8)\end{array}$ \\
\hline Reminder & $\begin{array}{c}0.0103 \\
(0.0207)\end{array}$ & $\begin{array}{l}-0.0647 \\
(0.634)\end{array}$ & $\begin{array}{l}-0.0221^{* *} \\
(0.00965)\end{array}$ & $\begin{array}{l}-0.617^{\star *} \\
(0.261)\end{array}$ & $\begin{array}{l}-0.0160 \\
(0.0136)\end{array}$ & $\begin{array}{l}-0.554^{\star} \\
(0.291)\end{array}$ & $\begin{array}{l}0.00960 \\
(0.0283)\end{array}$ & $\begin{array}{c}0.544 \\
(0.658)\end{array}$ \\
\hline Social & $\begin{array}{l}-0.0183 \\
(0.0210)\end{array}$ & $\begin{array}{l}-0.458 \\
(0.644)\end{array}$ & $\begin{array}{l}-0.0192^{\star *} \\
(0.00951)\end{array}$ & $\begin{array}{l}-0.358 \\
(0.257)\end{array}$ & $\begin{array}{l}-0.0257^{\star} \\
(0.0136)\end{array}$ & $\begin{array}{c}-0.896^{\star \star \star} \\
(0.292)\end{array}$ & $\begin{array}{c}0.0136 \\
(0.0282)\end{array}$ & $\begin{array}{c}1.199^{\star} \\
(0.655)\end{array}$ \\
\hline Constant & $\begin{array}{l}0.491^{*} \\
(0.268)\end{array}$ & $\begin{array}{c}-0.299 \\
(11.25)\end{array}$ & $\begin{array}{c}0.374 \\
(0.269)\end{array}$ & $\begin{array}{l}11.87^{*} \\
(6.202)\end{array}$ & $\begin{array}{c}0.268 \\
(0.234)\end{array}$ & $\begin{array}{l}-1.455 \\
(5.520)\end{array}$ & $\begin{array}{c}0.297 \\
(0.794)\end{array}$ & $\begin{array}{l}-1.039 \\
(6.801)\end{array}$ \\
\hline $\begin{array}{l}\text { Controls } \\
\text { Library FE }\end{array}$ & $\begin{array}{l}\text { YES } \\
\text { YES }\end{array}$ & $\begin{array}{l}\text { YES } \\
\text { YES }\end{array}$ & $\begin{array}{l}\text { YES } \\
\text { YES }\end{array}$ & $\begin{array}{l}\text { YES } \\
\text { YES }\end{array}$ & $\begin{array}{l}\text { YES } \\
\text { YES }\end{array}$ & $\begin{array}{l}\text { YES } \\
\text { YES }\end{array}$ & $\begin{array}{l}\text { YES } \\
\text { YES }\end{array}$ & $\begin{array}{l}\text { YES } \\
\text { YES }\end{array}$ \\
\hline $\begin{array}{l}\text { R-squared } \\
\text { Number of user }\end{array}$ & $\begin{array}{l}0.144 \\
1969 \\
\end{array}$ & $\begin{array}{l}0.115 \\
1877 \\
\end{array}$ & $\begin{array}{l}0.158 \\
8325 \\
\end{array}$ & $\begin{array}{l}0.131 \\
8039 \\
\end{array}$ & $\begin{array}{l}0.158 \\
3486 \\
\end{array}$ & $\begin{array}{l}0.187 \\
3418 \\
\end{array}$ & $\begin{array}{c}0.231 \\
662 \\
\end{array}$ & $\begin{array}{c}0.276 \\
656 \\
\end{array}$ \\
\hline Reminder & $\begin{array}{l}0.00779 \\
(0.0316)\end{array}$ & $\begin{array}{l}-0.796 \\
(0.997)\end{array}$ & $\begin{array}{c}-0.0343^{\star \star *} \\
(0.0128)\end{array}$ & $\begin{array}{l}-0.558 \\
(0.359)\end{array}$ & $\begin{array}{l}-0.0106 \\
(0.0204)\end{array}$ & $\begin{array}{l}-0.641 \\
(0.458)\end{array}$ & $\begin{array}{l}-0.0486 \\
(0.0525)\end{array}$ & $\begin{array}{l}-0.275 \\
(1.285)\end{array}$ \\
\hline Social & $\begin{array}{l}-0.0254 \\
(0.0322)\end{array}$ & $\begin{array}{l}-2.272^{\star \star} \\
(1.004)\end{array}$ & $\begin{array}{l}-0.0241^{*} \\
(0.0127)\end{array}$ & $\begin{array}{l}-0.278 \\
(0.356)\end{array}$ & $\begin{array}{l}-0.0390^{\star} \\
(0.0205)\end{array}$ & $\begin{array}{l}-0.731 \\
(0.459)\end{array}$ & $\begin{array}{l}-0.0782 \\
(0.0513)\end{array}$ & $\begin{array}{c}1.296 \\
(1.251)\end{array}$ \\
\hline Late & $\begin{array}{c}0.0195 \\
(0.0314)\end{array}$ & $\begin{array}{l}-1.416 \\
(0.991)\end{array}$ & $\begin{array}{c}-0.0328^{\star \star \star} \\
(0.0126)\end{array}$ & $\begin{array}{l}-0.397 \\
(0.352)\end{array}$ & $\begin{array}{l}-0.0177 \\
(0.0207)\end{array}$ & $\begin{array}{l}-0.466 \\
(0.467)\end{array}$ & $\begin{array}{l}-0.107^{\star *} \\
(0.0496)\end{array}$ & $\begin{array}{l}-0.733 \\
(1.213)\end{array}$ \\
\hline Penalty & $\begin{array}{l}0.00236 \\
(0.0314)\end{array}$ & $\begin{array}{l}-2.216^{\star \star} \\
(0.991)\end{array}$ & $\begin{array}{c}-0.0456^{\star \star \star} \\
(0.0126)\end{array}$ & $\begin{array}{l}-0.555 \\
(0.355)\end{array}$ & $\begin{array}{l}-0.0480^{\star *} \\
(0.0206)\end{array}$ & $\begin{array}{l}-1.184^{\star \star} \\
(0.462)\end{array}$ & $\begin{array}{l}-0.0877^{\star} \\
(0.0511)\end{array}$ & $\begin{array}{c}-0.531 \\
(1.251)\end{array}$ \\
\hline Constant & $\begin{array}{l}-0.0151 \\
(0.267)\end{array}$ & $\begin{array}{l}-2.664 \\
(8.162)\end{array}$ & $\begin{array}{c}0.154 \\
(0.225)\end{array}$ & $\begin{array}{l}10.66^{\star *} \\
(4.874)\end{array}$ & $\begin{array}{c}0.528 \\
(0.339)\end{array}$ & $\begin{array}{l}-5.538 \\
(9.654)\end{array}$ & $\begin{array}{l}-2.334 \\
(3.754)\end{array}$ & $\begin{array}{l}-58.65 \\
(91.07)\end{array}$ \\
\hline $\begin{array}{l}\text { Controls } \\
\text { Library FE }\end{array}$ & $\begin{array}{l}\text { YES } \\
\text { YES }\end{array}$ & $\begin{array}{l}\text { YES } \\
\text { YES }\end{array}$ & $\begin{array}{l}\text { YES } \\
\text { YES }\end{array}$ & $\begin{array}{l}\text { YES } \\
\text { YES }\end{array}$ & $\begin{array}{l}\text { YES } \\
\text { YES }\end{array}$ & $\begin{array}{l}\text { YES } \\
\text { YES }\end{array}$ & $\begin{array}{l}\text { YES } \\
\text { YES }\end{array}$ & $\begin{array}{l}\text { YES } \\
\text { YES }\end{array}$ \\
\hline $\begin{array}{l}\text { R-squared } \\
\text { Number of users }\end{array}$ & $\begin{array}{l}0.132 \\
1416 \\
\end{array}$ & $\begin{array}{l}0.122 \\
1331 \\
\end{array}$ & $\begin{array}{l}0.159 \\
7770 \\
\end{array}$ & $\begin{array}{l}0.135 \\
7473 \\
\end{array}$ & $\begin{array}{l}0.155 \\
2609 \\
\end{array}$ & $\begin{array}{l}0.171 \\
2540 \\
\end{array}$ & $\begin{array}{c}0.254 \\
410 \\
\end{array}$ & $\begin{array}{c}0.271 \\
406 \\
\end{array}$ \\
\hline
\end{tabular}

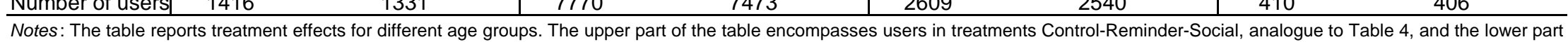
Notes: The table reports treatment effects for different age groups. The upper part of the table encompasses users in treatments Control-Reminder-Social, analogue to Table 4, and the lower part
of the table corresponds to late users in treatments Control-Reminder-Social-Late-Penalty, analogue to Table 5 . The full set of controls is used, as well as the library fixed effects. See the notes from previous tables. Robust standard errors in paranthesis. ${ }^{\star}$ : significant at the $10 \%$ level; ${ }^{\star *}$ : significant at the $5 \%$ level; ${ }^{\star * *}$ : significant at the $1 \%$ level. 
Table 10

Differential Treatment Effect by Gender

\begin{tabular}{|c|c|c|c|c|}
\hline & \multicolumn{2}{|c|}{ Control-Reminder-Social } & \multicolumn{2}{|c|}{ Control-Reminder-Social-Late-Penalty } \\
\hline & $\begin{array}{c}\text { Proportion Late } \\
(1)\end{array}$ & $\begin{array}{c}\text { "Actual - Due" Date } \\
(2)\end{array}$ & $\begin{array}{c}\text { Proportion Late } \\
\text { (3) }\end{array}$ & $\begin{array}{c}\text { "Actual - Due" Date } \\
(4)\end{array}$ \\
\hline Reminder & $\begin{array}{l}-0.00770 \\
(0.00945)\end{array}$ & $\begin{array}{l}-0.255 \\
(0.250)\end{array}$ & $\begin{array}{l}-0.0200 \\
(0.0134)\end{array}$ & $\begin{array}{l}-0.302 \\
(0.368)\end{array}$ \\
\hline Social & $\begin{array}{l}-0.0207^{\star *} \\
(0.00936)\end{array}$ & $\begin{array}{l}-0.255 \\
(0.247)\end{array}$ & $\begin{array}{c}-0.0345^{\star \star \star} \\
(0.0133)\end{array}$ & $\begin{array}{l}-0.169 \\
(0.366)\end{array}$ \\
\hline Late & & & $\begin{array}{l}-0.0213 \\
(0.0132)\end{array}$ & $\begin{array}{l}-0.0801 \\
(0.363)\end{array}$ \\
\hline Penalty & & & $\begin{array}{l}-0.0475^{\star \star \star} \\
(0.0132)\end{array}$ & $\begin{array}{l}-0.915^{\star \star} \\
(0.364)\end{array}$ \\
\hline Male & $\begin{array}{l}0.00132 \\
(0.0102)\end{array}$ & $\begin{array}{l}0.0613 \\
(0.270)\end{array}$ & $\begin{array}{r}-0.00120 \\
(0.0144)\end{array}$ & $\begin{array}{c}0.382 \\
(0.394)\end{array}$ \\
\hline Reminder* Male & $\begin{array}{l}-0.0141 \\
(0.0145)\end{array}$ & $\begin{array}{l}-0.497 \\
(0.382)\end{array}$ & $\begin{array}{l}-0.00885 \\
(0.0203)\end{array}$ & $\begin{array}{l}-0.721 \\
(0.557)\end{array}$ \\
\hline Social*Male & $\begin{array}{l}0.00552 \\
(0.0144)\end{array}$ & $\begin{array}{l}-0.363 \\
(0.379)\end{array}$ & $\begin{array}{c}0.0110 \\
(0.0202)\end{array}$ & $\begin{array}{l}-0.874 \\
(0.554)\end{array}$ \\
\hline Late*Male & & & $\begin{array}{l}-0.0134 \\
(0.0201)\end{array}$ & $\begin{array}{l}-1.078^{*} \\
(0.551)\end{array}$ \\
\hline PenaltyMale & & & $\begin{array}{l}0.00979 \\
(0.0201)\end{array}$ & $\begin{array}{l}0.0793 \\
(0.553)\end{array}$ \\
\hline Constant & $\begin{array}{l}0.375^{\star *} \\
(0.146)\end{array}$ & $\begin{array}{c}4.618 \\
(4.107)\end{array}$ & $\begin{array}{c}0.156 \\
(0.150)\end{array}$ & $\begin{array}{c}4.014 \\
(3.695)\end{array}$ \\
\hline Controls & YES & YES & YES & YES \\
\hline Library FE & YES & YES & YES & YES \\
\hline R-squared & 0.166 & 0.138 & 0.161 & 0.135 \\
\hline Number of users & 14442 & 13990 & 12205 & 11750 \\
\hline
\end{tabular}

Notes: The table reports the differential treatment effect with respect to gender. Male is a dummy variable taking a value of 1 in case of male, and 0 in case of female. The full set of controls is used, as well as the library fixed effects. See the notes from previous tables. Robust standard errors in parantheses *: significant at the $10 \%$ level; ${ }^{* *}$ : significant at the $5 \%$ level; $* * *$ : significant at the $1 \%$ level. 
TABLE 11

Treatment Effects by Nationality

Part 1

\begin{tabular}{|c|c|c|c|c|c|c|c|c|}
\hline & $\begin{array}{c}\text { Spain } \\
(1)\end{array}$ & $\begin{array}{c}\text { Northern-Central Europe } \\
(2)\end{array}$ & $\begin{array}{c}\text { West-South Europe } \\
(3) \\
\end{array}$ & $\begin{array}{c}\text { English Speaking } \\
(4)\end{array}$ & $\begin{array}{c}\text { Eastern-Russia } \\
\text { (5) } \\
\end{array}$ & $\begin{array}{c}\text { Latin America } \\
(6) \\
\end{array}$ & $\begin{array}{c}\text { Asia } \\
(7)\end{array}$ & $\begin{array}{c}\text { Africa } \\
(8)\end{array}$ \\
\hline & \multicolumn{8}{|c|}{$\begin{array}{ll}\text { Proportion Late } \\
\end{array}$} \\
\hline Reminder & $\begin{array}{l}-0.0111 \\
(0.00839)\end{array}$ & $\begin{array}{l}-0.00536 \\
(0.0550)\end{array}$ & $\begin{array}{l}-0.00472 \\
(0.0315)\end{array}$ & $\begin{array}{l}-0.123^{\star *} \\
(0.0558)\end{array}$ & $\begin{array}{c}0.0915 \\
(0.0677)\end{array}$ & $\begin{array}{l}-0.0254 \\
(0.0180)\end{array}$ & $\begin{array}{l}-0.0666 \\
(0.102)\end{array}$ & $\begin{array}{l}-0.0338 \\
(0.0645)\end{array}$ \\
\hline Social & $\begin{array}{l}-0.0148^{*} \\
(0.00834)\end{array}$ & $\begin{array}{l}-0.0456 \\
(0.0564)\end{array}$ & $\begin{array}{l}0.00147 \\
(0.0310)\end{array}$ & $\begin{array}{l}-0.207^{\star \star *} \\
(0.0544)\end{array}$ & $\begin{array}{l}-0.0164 \\
(0.0661)\end{array}$ & $\begin{array}{l}-0.0227 \\
(0.0178)\end{array}$ & $\begin{array}{c}0.101 \\
(0.0869)\end{array}$ & $\begin{array}{l}-0.0639 \\
(0.0649)\end{array}$ \\
\hline Constant & $\begin{array}{l}0.260^{\star * *} \\
(0.0131)\end{array}$ & $\begin{array}{c}0.411^{* * *} \\
(0.111)\end{array}$ & $\begin{array}{l}0.280^{* * *} \\
(0.0816)\end{array}$ & $\begin{array}{l}0.294^{* *} \\
(0.116)\end{array}$ & $\begin{array}{l}0.182^{*} \\
(0.101)\end{array}$ & $\begin{array}{l}0.308^{* * *} \\
(0.0311)\end{array}$ & $\begin{array}{c}-0.0764 \\
(0.147)\end{array}$ & $\begin{array}{c}0.392^{\star * *} \\
(0.132)\end{array}$ \\
\hline Controls & YES & YES & YES & YES & YES & YES & YES & YES \\
\hline $\begin{array}{l}\text { R-squared } \\
\text { Number of users }\end{array}$ & $\begin{array}{c}0.152 \\
10395 \\
\end{array}$ & $\begin{array}{c}0.126 \\
265 \\
\end{array}$ & $\begin{array}{c}0.190 \\
745 \\
\end{array}$ & $\begin{array}{c}0.261 \\
224 \\
\end{array}$ & $\begin{array}{c}0.226 \\
185 \\
\end{array}$ & $\begin{array}{l}0.167 \\
2369 \\
\end{array}$ & $\begin{array}{c}0.413 \\
84\end{array}$ & $\begin{array}{c}0.218 \\
174 \\
\end{array}$ \\
\hline & \multicolumn{8}{|c|}{ "Actual - Due" Date } \\
\hline Reminder & $\begin{array}{l}-0.373^{\star} \\
(0.216)\end{array}$ & $\begin{array}{l}-0.320 \\
(1.138)\end{array}$ & $\begin{array}{l}-0.708 \\
(0.907)\end{array}$ & $\begin{array}{l}-1.536 \\
(2.002)\end{array}$ & $\begin{array}{l}-1.367 \\
(1.784)\end{array}$ & $\begin{array}{l}-0.418 \\
(0.513)\end{array}$ & $\begin{array}{l}-0.546 \\
(1.983)\end{array}$ & $\begin{array}{l}-1.282 \\
(1.209)\end{array}$ \\
\hline Social & $\begin{array}{l}-0.348 \\
(0.215)\end{array}$ & $\begin{array}{c}0.331 \\
(1.175)\end{array}$ & $\begin{array}{l}-0.271 \\
(0.896)\end{array}$ & $\begin{array}{c}-5.488^{\star \star \star} \\
(1.959)\end{array}$ & $\begin{array}{c}-2.503 \\
(1.700)\end{array}$ & $\begin{array}{c}0.113 \\
(0.507)\end{array}$ & $\begin{array}{c}1.923 \\
(1.705)\end{array}$ & $\begin{array}{c}0.661 \\
(1.220)\end{array}$ \\
\hline Constant & $\begin{array}{c}1.128^{* * *} \\
(0.327)\end{array}$ & $\begin{array}{l}-1.086 \\
(2.435)\end{array}$ & $\begin{array}{c}2.929 \\
(2.310)\end{array}$ & $\begin{array}{c}5.396 \\
(4.047)\end{array}$ & $\begin{array}{c}3.961 \\
(2.442)\end{array}$ & $\begin{array}{c}1.627^{*} \\
(0.863)\end{array}$ & $\begin{array}{c}-7.904^{\star * *} \\
(2.664)\end{array}$ & $\begin{array}{l}-3.444 \\
(2.719)\end{array}$ \\
\hline Controls & YES & YES & YES & YES & YES & YES & YES & YES \\
\hline $\begin{array}{l}\text { R-squared } \\
\text { Number of users }\end{array}$ & $\begin{array}{r}0.125 \\
10091 \\
\end{array}$ & $\begin{array}{c}0.169 \\
256\end{array}$ & $\begin{array}{c}0.192 \\
721 \\
\end{array}$ & $\begin{array}{c}0.124 \\
216 \\
\end{array}$ & $\begin{array}{c}0.136 \\
178 \\
\end{array}$ & $\begin{array}{l}0.112 \\
2284 \\
\end{array}$ & $\begin{array}{c}0.396 \\
82 \\
\end{array}$ & $\begin{array}{c}0.295 \\
168 \\
\end{array}$ \\
\hline
\end{tabular}


Part 2

\begin{tabular}{|c|c|c|c|c|c|c|c|c|}
\hline & $\begin{array}{c}\text { Spain } \\
(1)\end{array}$ & $\begin{array}{c}\text { Northern-Central Europe } \\
(2) \\
\end{array}$ & $\begin{array}{c}\text { West-South Europe } \\
(3)\end{array}$ & $\begin{array}{c}\text { English Speaking } \\
(4) \\
\end{array}$ & $\begin{array}{c}\text { Eastern-Russia } \\
(5) \\
\end{array}$ & $\begin{array}{c}\text { Latin America } \\
(6) \\
\end{array}$ & $\begin{array}{c}\text { Asia } \\
(7)\end{array}$ & $\begin{array}{c}\text { Africa } \\
(8)\end{array}$ \\
\hline & \multicolumn{8}{|c|}{ Proportion Late } \\
\hline \multirow{2}{*}{ Reminder } & -0.0184 & 0.0258 & 0.0133 & $-0.224^{\star \star \star}$ & 0.0315 & $-0.0401^{\star}$ & $-0.206^{\star}$ & 0.0364 \\
\hline & $(0.0123)$ & $(0.0669)$ & $(0.0407)$ & $(0.0690)$ & $(0.0868)$ & $(0.0236)$ & $(0.111)$ & $(0.0717)$ \\
\hline \multirow{2}{*}{ Social } & $-0.0253^{\star *}$ & -0.0150 & 0.0139 & $-0.295^{\star \star \star}$ & -0.0788 & -0.0256 & -0.0211 & -0.00248 \\
\hline & $(0.0122)$ & $(0.0681)$ & $(0.0393)$ & $(0.0684)$ & $(0.0825)$ & $(0.0233)$ & $(0.100)$ & $(0.0731)$ \\
\hline \multirow[t]{2}{*}{ Late } & $-0.0290^{\star *}$ & 0.0840 & -0.0156 & $-0.186^{\star * \star}$ & 0.0615 & -0.0108 & $-0.207^{* *}$ & -0.00601 \\
\hline & $(0.0121)$ & $(0.0669)$ & $(0.0396)$ & $(0.0659)$ & $(0.0820)$ & $(0.0235)$ & $(0.0994)$ & $(0.0718)$ \\
\hline \multirow[t]{2}{*}{ Penalty } & $-0.0427^{\star \star \star}$ & 0.0263 & -0.0463 & $-0.245^{\star \star \star}$ & -0.0659 & -0.0111 & $-0.280^{* * *}$ & 0.0364 \\
\hline & $(0.0122)$ & $(0.0710)$ & $(0.0387)$ & $(0.0662)$ & $(0.0825)$ & $(0.0233)$ & $(0.104)$ & $(0.0781)$ \\
\hline Constant & $\begin{array}{l}0.274^{* * *} \\
(0.0172)\end{array}$ & $\begin{array}{c}0.299 \\
(0.184)\end{array}$ & $\begin{array}{l}0.217^{* *} \\
(0.0927)\end{array}$ & $\begin{array}{l}0.444^{* * *} \\
(0.124)\end{array}$ & $\begin{array}{c}0.112 \\
(0.115)\end{array}$ & $\begin{array}{l}0.361^{* * *} \\
(0.0366)\end{array}$ & $\begin{array}{l}0.0430 \\
(0.141)\end{array}$ & $\begin{array}{c}0.121 \\
(0.196)\end{array}$ \\
\hline Controls & YES & YES & YES & YES & YES & YES & YES & YES \\
\hline R-squared & 0.144 & 0.261 & 0.195 & 0.286 & 0.273 & 0.156 & 0.519 & 0.381 \\
\hline \multirow[t]{2}{*}{ Number of users } & 8198 & 241 & 778 & 230 & 195 & 2308 & 79 & 162 \\
\hline & \multicolumn{8}{|c|}{ "Actual - Due" Date } \\
\hline \multirow[t]{2}{*}{ Reminder } & -0.413 & 0.750 & 0.174 & $-6.450^{\star \star \star}$ & -2.588 & -0.797 & -1.796 & 0.985 \\
\hline & $(0.332)$ & $(1.764)$ & $(1.082)$ & $(2.341)$ & $(2.457)$ & $(0.689)$ & $(2.344)$ & (1.888) \\
\hline \multirow[t]{2}{*}{ Social } & -0.343 & 2.613 & 0.138 & $-8.512^{\star \star \star}$ & $-4.938^{\star \star}$ & -0.373 & 2.943 & $3.663^{*}$ \\
\hline & $(0.332)$ & (1.792) & $(1.051)$ & $(2.333)$ & $(2.298)$ & $(0.679)$ & $(2.104)$ & $(1.908)$ \\
\hline \multirow[t]{2}{*}{ Late } & $-0.638^{*}$ & $3.497^{\star \star}$ & -0.0316 & $-7.432^{\star \star \star}$ & -1.902 & 0.605 & -1.128 & 2.170 \\
\hline & $(0.329)$ & $(1.748)$ & $(1.060)$ & $(2.239)$ & $(2.294)$ & $(0.683)$ & (2.079) & $(1.863)$ \\
\hline \multirow[t]{2}{*}{ Penalty } & $-0.823^{\star \star}$ & 2.547 & -1.331 & $-7.085^{\star \star \star}$ & $-5.103^{\star \star}$ & -0.0294 & -2.397 & 1.890 \\
\hline & $(0.331)$ & $(1.861)$ & $(1.040)$ & (2.219) & $(2.317)$ & $(0.684)$ & $(2.157)$ & (2.045) \\
\hline Constant & $\begin{array}{l}1.676^{* * *} \\
(0.428)\end{array}$ & $\begin{array}{l}0.0302 \\
(5.358)\end{array}$ & $\begin{array}{l}-1.796 \\
(2.456)\end{array}$ & $\begin{array}{l}12.88^{\star * *} \\
(4.090)\end{array}$ & $\begin{array}{l}3.520 \\
(2.960)\end{array}$ & $\begin{array}{c}2.639^{* * *} \\
(1.008)\end{array}$ & $\begin{array}{l}-5.836^{\star \star} \\
(2.813)\end{array}$ & $\begin{array}{l}-2.556 \\
(5.892)\end{array}$ \\
\hline Controls & YES & YES & YES & YES & YES & YES & YES & YES \\
\hline R-squared & 0.112 & 0.182 & 0.206 & 0.166 & 0.198 & 0.130 & 0.442 & 0.281 \\
\hline Number of users & 7902 & 237 & 747 & 217 & 184 & 2222 & 78 & 158 \\
\hline
\end{tabular}


TABLE A.1

Prop. of Late Returns for Different Nationality Groups

\begin{tabular}{|c|c|c|}
\hline & $\begin{array}{c}\text { Prior Late } \\
\text { (1) }\end{array}$ & $\begin{array}{l}\text { Prop. Late } \\
\text { (2) }\end{array}$ \\
\hline \multirow{2}{*}{ Europe-North-Central } & -0.0130 & 0.0106 \\
\hline & $(0.0174)$ & $(0.0277)$ \\
\hline \multirow[t]{2}{*}{ Europe-West-South } & $0.0239 * \star \star$ & $0.0335^{\star \star \star}$ \\
\hline & $(0.00707)$ & $(0.0105)$ \\
\hline \multirow[t]{2}{*}{ English Speaking Countries } & $0.0365^{\star \star \star}$ & $0.0426^{\star \star}$ \\
\hline & $(0.0116)$ & $(0.0179)$ \\
\hline \multirow[t]{2}{*}{ Russia-East } & 0.00677 & $0.0445^{\star \star}$ \\
\hline & $(0.0130)$ & $(0.0193)$ \\
\hline \multirow[t]{2}{*}{ Latin America } & $0.0284^{\star \star \star}$ & $0.0542^{\star \star \star}$ \\
\hline & $(0.00436)$ & $(0.00645)$ \\
\hline \multirow[t]{2}{*}{ Asia } & $-0.0614^{\star \star \star}$ & -0.0174 \\
\hline & $(0.0175)$ & $(0.0283)$ \\
\hline \multirow[t]{2}{*}{ Africa } & -0.00218 & -0.0351 \\
\hline & $(0.0217)$ & $(0.0337)$ \\
\hline Constant & $\begin{array}{l}0.415^{\star * *} \\
(0.0129)\end{array}$ & $\begin{array}{l}0.300^{* *} \\
(0.130)\end{array}$ \\
\hline Controls & YES & YES \\
\hline R-squared & 0.045 & 0.092 \\
\hline Number of users & 60215 & 25896 \\
\hline \multicolumn{3}{|c|}{$\begin{array}{l}\text { Notes: The table reports proportion of late returns per user for different } \\
\text { groups of nationalities. The omitted variable is Spaniards. Column (1) refers } \\
\text { to the pre-treatment period and column (2) to the post-treatment period. } \\
\text { Full set of controls is used. Robust standard errors in parantheses } \\
\text { significant at the } 10 \% \text { level; }{ }^{* *} \text { : significant at the } 5 \% \text { level; }{ }^{* *} \text { : significant at } \\
\text { the } 1 \% \text { level. }\end{array}$} \\
\hline
\end{tabular}


TABLE A.2

English Speaking Countries compared to Spain

\begin{tabular}{|c|c|c|c|c|}
\hline & $\begin{array}{l}\text { Prop. Late } \\
\text { (1) }\end{array}$ & $\begin{array}{c}\text { "Actual - Due" Date } \\
(2)\end{array}$ & $\begin{array}{l}\text { Prop. Late } \\
\text { (3) }\end{array}$ & $\begin{array}{c}\text { "Actual - Due" Date } \\
(4)\end{array}$ \\
\hline Reminder & $\begin{array}{c}-0.00797 \\
(0.0112)\end{array}$ & $\begin{array}{c}-0.469^{\star *} \\
(0.218)\end{array}$ & $\begin{array}{l}-0.00221 \\
(0.0230)\end{array}$ & $\begin{array}{c}-0.309 \\
(0.336)\end{array}$ \\
\hline Social & $\begin{array}{l}-0.0112 \\
(0.0111)\end{array}$ & $\begin{array}{l}-0.372^{*} \\
(0.218)\end{array}$ & $\begin{array}{l}-0.0308 \\
(0.0230)\end{array}$ & $\begin{array}{l}-0.390 \\
(0.336)\end{array}$ \\
\hline Late & & & $\begin{array}{l}-0.0526^{* *} \\
(0.0229)\end{array}$ & $\begin{array}{l}-0.642^{*} \\
(0.334)\end{array}$ \\
\hline Penalty & & & $\begin{array}{l}-0.0451^{* *} \\
(0.0227)\end{array}$ & $\begin{array}{l}-0.833^{* *} \\
(0.336)\end{array}$ \\
\hline English & $\begin{array}{l}0.149^{* * *} \\
(0.0386)\end{array}$ & $\begin{array}{l}3.579^{* * *} \\
(0.999)\end{array}$ & $\begin{array}{l}0.183^{\star * *} \\
(0.0504)\end{array}$ & $\begin{array}{l}6.264^{* * *} \\
(1.370)\end{array}$ \\
\hline ReminderEnglish & $\begin{array}{l}-0.117^{\star \star} \\
(0.0574)\end{array}$ & $\begin{array}{l}-1.543 \\
(1.494)\end{array}$ & $\begin{array}{l}-0.184^{\star \star} \\
(0.0751)\end{array}$ & $\begin{array}{l}-5.626^{\star \star \star} \\
(2.050)\end{array}$ \\
\hline Social*English & $\begin{array}{l}-0.195^{\star \star *} \\
(0.0566)\end{array}$ & $\begin{array}{l}-4.892^{\star \star *} \\
(1.470)\end{array}$ & $\begin{array}{l}-0.255^{\star \star \star} \\
(0.0741)\end{array}$ & $\begin{array}{c}-7.623^{\star \star \star} \\
(2.035)\end{array}$ \\
\hline Late`English & & & $\begin{array}{l}-0.148^{\star *} \\
(0.0706)\end{array}$ & $\begin{array}{c}-7.308^{* * *} \\
(1.942)\end{array}$ \\
\hline PenaltyEnglish & & & $\begin{array}{l}-0.223^{\star \star \star} \\
(0.0721)\end{array}$ & $\begin{array}{l}-6.586^{\star \star *} \\
(1.963)\end{array}$ \\
\hline Prior Late & $\begin{array}{l}0.319^{\star * *} \\
(0.0173)\end{array}$ & & $\begin{array}{l}0.277^{* * *} \\
(0.0277)\end{array}$ & \\
\hline Prior "Actual - Due" & & $\begin{array}{l}0.209^{* * *} \\
(0.0191)\end{array}$ & & $\begin{array}{l}0.193^{* * *} \\
(0.0264)\end{array}$ \\
\hline Reminder ${ }^{\star}$ Prior Late & $\begin{array}{l}-0.0124 \\
(0.0247)\end{array}$ & & $\begin{array}{l}-0.0343 \\
(0.0393)\end{array}$ & \\
\hline Social ${ }^{\star}$ Prior Late & $\begin{array}{l}-0.0158 \\
(0.0246)\end{array}$ & & $\begin{array}{l}0.00553 \\
(0.0393)\end{array}$ & \\
\hline ReminderPrior "Actual - Due & & $\begin{array}{l}-0.0571^{* *} \\
(0.0258)\end{array}$ & & $\begin{array}{c}-0.0933^{* * *} \\
(0.0340)\end{array}$ \\
\hline Social"Prior "Actual - Due" & & $\begin{array}{l}0.0185 \\
(0.0276)\end{array}$ & & $\begin{array}{l}-0.0427 \\
(0.0375)\end{array}$ \\
\hline Late ${ }^{\star}$ Prior Late & & & $\begin{array}{c}0.0445 \\
(0.0389)\end{array}$ & \\
\hline Penalty*Prior Late & & & $\begin{array}{l}-0.00215 \\
(0.0386)\end{array}$ & \\
\hline Late*Prior "Actual - Due" & & & & $\begin{array}{l}-0.0503 \\
(0.0347)\end{array}$ \\
\hline Penalty*Prior "Actual - Due" & & & & $\begin{array}{l}-0.0816^{* *} \\
(0.0379)\end{array}$ \\
\hline Constant & $\begin{array}{c}0.332 \\
(0.208)\end{array}$ & $\begin{array}{l}3.382 \\
(5.707)\end{array}$ & $\begin{array}{c}0.164 \\
(0.215)\end{array}$ & $\begin{array}{l}-0.333 \\
(6.254)\end{array}$ \\
\hline $\begin{array}{l}\text { Controls } \\
\text { Library FE }\end{array}$ & $\begin{array}{l}\text { YES } \\
\text { YES }\end{array}$ & $\begin{array}{l}\text { YES } \\
\text { YES }\end{array}$ & $\begin{array}{l}\text { YES } \\
\text { YES }\end{array}$ & $\begin{array}{l}\text { YES } \\
\text { YES }\end{array}$ \\
\hline $\begin{array}{l}\text { R-squared } \\
\text { Number of users }\end{array}$ & $\begin{array}{l}0.161 \\
10619 \\
\end{array}$ & $\begin{array}{l}0.137 \\
10307 \\
\end{array}$ & $\begin{array}{l}0.156 \\
8428 \\
\end{array}$ & $\begin{array}{l}0.131 \\
8119 \\
\end{array}$ \\
\hline
\end{tabular}

Notes: The table reports differential treatment effects for users from the English speaking countries. The reference group is Spaniards (omitted). Interaction terms for differential treatment effects for users in the English speaking countries are shown. Interaction terms for differential treatment effects based on the behavior prior to the treatment are included. Full set of controls, as well as library fixed effects are included. See the notes from previous tables. Robust standard errors in parantheses *: significant at the $10 \%$ level; **: significant at the $5 \%$ level; ${ }^{* * *}$ : significant at the $1 \%$ level. 
TABLE A.3

Asia compared to Spain

\begin{tabular}{|c|c|c|c|c|}
\hline & $\begin{array}{l}\text { Prop. Late } \\
\text { (1) }\end{array}$ & $\begin{array}{c}\text { "Actual - Due" Date } \\
(2)\end{array}$ & $\begin{array}{l}\text { Prop. Late } \\
(3)\end{array}$ & $\begin{array}{c}\text { "Actual - Due" Date } \\
(4)\end{array}$ \\
\hline \multirow[t]{2}{*}{ Reminder } & -0.00642 & $-0.471^{\star \star}$ & 0.00319 & -0.310 \\
\hline & $(0.0112)$ & $(0.216)$ & $(0.0232)$ & $(0.334)$ \\
\hline \multirow{2}{*}{ Social } & -0.0113 & $-0.373^{\star}$ & -0.0297 & -0.396 \\
\hline & $(0.0111)$ & $(0.216)$ & (0.0232) & $(0.334)$ \\
\hline \multirow[t]{2}{*}{ Late } & & & $-0.0430^{\star}$ & $-0.652^{\star *}$ \\
\hline & & & $(0.0231)$ & $(0.332)$ \\
\hline \multirow[t]{2}{*}{ Penalty } & & & $-0.0411^{*}$ & $-0.839^{* *}$ \\
\hline & & & $(0.0229)$ & $(0.334)$ \\
\hline \multirow{2}{*}{ UKA-USA } & -0.0374 & -1.393 & 0.0860 & -0.246 \\
\hline & $(0.0746)$ & (1.888) & $(0.0974)$ & $(2.580)$ \\
\hline \multirow[t]{2}{*}{ Reminder*Asia } & -0.110 & -0.759 & $-0.267^{\star}$ & -2.578 \\
\hline & $(0.105)$ & (2.699) & $(0.141)$ & (3.808) \\
\hline \multirow[t]{2}{*}{ Social ${ }^{\star}$ Asia } & 0.124 & 2.217 & -0.00630 & 1.402 \\
\hline & $(0.0929)$ & $(2.361)$ & $(0.129)$ & (3.429) \\
\hline \multirow[t]{2}{*}{ Late*Asia } & & & -0.194 & -1.744 \\
\hline & & & $(0.126)$ & (3.351) \\
\hline \multirow{2}{*}{ Penalty ${ }^{\star}$ Asia } & & & $-0.264^{\star *}$ & -2.815 \\
\hline & & & $(0.128)$ & (3.386) \\
\hline Prior Late & $\begin{array}{l}0.320^{\star * *} \\
(0.0174)\end{array}$ & & $\begin{array}{l}0.283^{\star \star *} \\
(0.0280)\end{array}$ & \\
\hline Prior "Actual - Due" & & $\begin{array}{l}0.204^{* * *} \\
(0.0191)\end{array}$ & & $\begin{array}{l}0.191^{* * *} \\
(0.0265)\end{array}$ \\
\hline Reminder*Prior Late & $\begin{array}{l}-0.0180 \\
(0.0249)\end{array}$ & & $\begin{array}{l}-0.0452 \\
(0.0396)\end{array}$ & \\
\hline Social ${ }^{*}$ Prior Late & $\begin{array}{l}-0.0162 \\
(0.0248)\end{array}$ & & $\begin{array}{l}0.00391 \\
(0.0397)\end{array}$ & \\
\hline Reminder*Prior "Actual - Due" & & $\begin{array}{l}-0.0564^{\star *} \\
(0.0255)\end{array}$ & & $\begin{array}{c}-0.0940^{\star * *} \\
(0.0338)\end{array}$ \\
\hline Social"Prior "Actual - Due" & & $\begin{array}{c}0.0215 \\
(0.0275)\end{array}$ & & $\begin{array}{l}-0.0390 \\
(0.0375)\end{array}$ \\
\hline Late ${ }^{\star}$ Prior Late & & & $\begin{array}{c}0.0258 \\
(0.0392)\end{array}$ & \\
\hline Penalty*Prior Late & & & $\begin{array}{c}-0.00934 \\
(0.0390)\end{array}$ & \\
\hline Late*Prior "Actual - Due" & & & & $\begin{array}{l}-0.0422 \\
(0.0352)\end{array}$ \\
\hline Penalty*Prior "Actual - Due" & & & & $\begin{array}{l}-0.0763^{\star \star} \\
(0.0378)\end{array}$ \\
\hline Constant & $\begin{array}{c}0.329 \\
(0.208)\end{array}$ & $\begin{array}{l}3.295 \\
(5.657)\end{array}$ & $\begin{array}{c}0.158 \\
(0.215)\end{array}$ & $\begin{array}{l}-0.454 \\
(6.216)\end{array}$ \\
\hline Controls & YES & YES & YES & YES \\
\hline Library FE & YES & YES & YES & YES \\
\hline R-squared & 0.159 & 0.137 & 0.155 & 0.131 \\
\hline Number of user & 10479 & 10173 & 8277 & 7980 \\
\hline
\end{tabular}

Notes: The table reports differential treatment effects for Asian users. The reference group is Spaniards (omitted). Interaction terms for differential treatment effects for Asia are shown. Interaction terms for differential treatment effects based on the behavior prior to the treatment are included. Full set of controls, as well as library fixed effects are included. See the notes from previous tables. Robust standard errors in parantheses *: significant at the $10 \%$ level; ${ }^{*}$ : significant at the $5 \%$ level; ${ }^{* * *}$ : significant at the $1 \%$ level. 